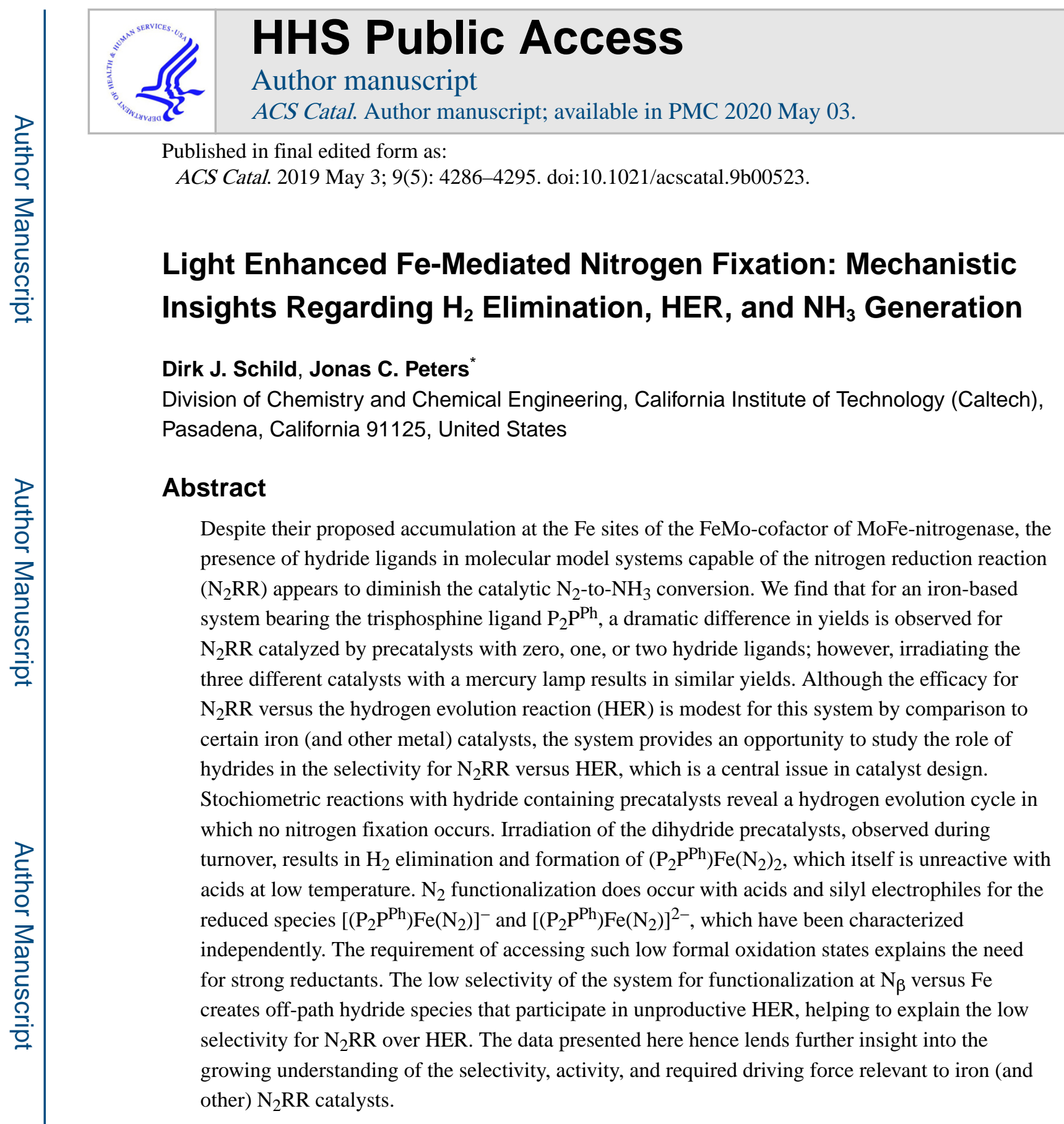

\title{
SYNOPSIS TOC
}

*Corresponding Author jpeters@caltech.edu. ASSOCIATED CONTENT

Supporting Information

The supporting information is available free of charge via the internet at http://pubs.acs.org.

Experimental procedures and compound characterization, X-ray data and Cartesian coordinates. CCDC 1886643-1886649 


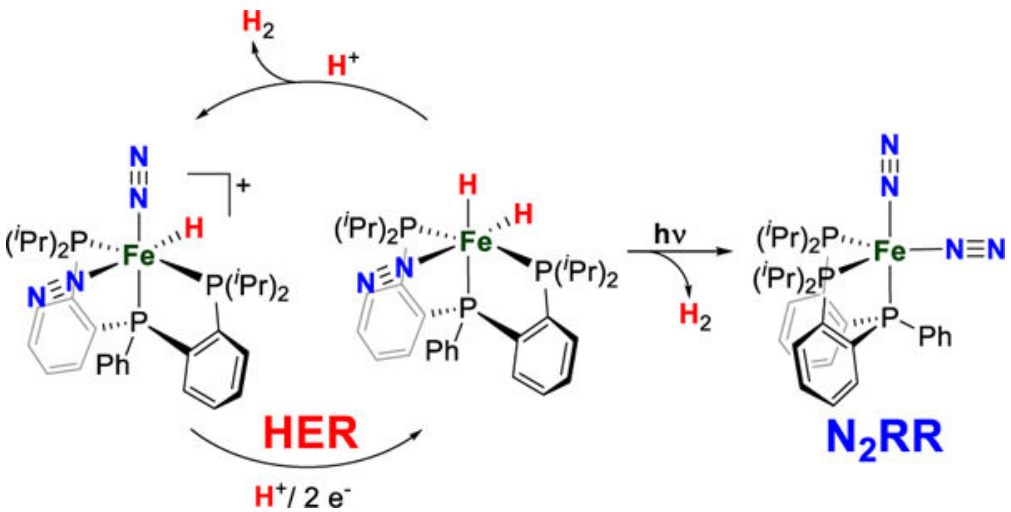

\section{Keywords}

ammonia synthesis; nitrogen fixation; $\mathrm{N}_{2} \mathrm{RR}$; nitrogenase; hydrogen evolution; HER; iron catalysis; photocatalysis

\section{Introduction}

Substantial progress has been made in the development and understanding of molecular catalysts for $\mathrm{N}_{2}$-to- $\mathrm{NH}_{3}$ conversion, commonly referred to as the nitrogen reduction reaction $\left(\mathrm{N}_{2} \mathrm{RR}\right) .{ }^{1-3}$ The number of well-defined complexes capable of $\mathrm{N}_{2} \mathrm{RR}$ is expanding rapidly, and significant improvements in turnover and efficiency have been made. ${ }^{4,5}$ With the growing number of systems available, it becomes increasingly possible to uncover general design principles that will aid in further progress for the field. The selectivity of $\mathrm{N}_{2} \mathrm{RR}$ versus the competing hydrogen evolution reaction (HER) is a central selectivity issue in need of model studies. ${ }^{6}$ Competing HER not only limits the efficiency of molecular catalyst systems but also limits nitrogenase enzymes. ${ }^{7,8}$ Additionally, and relatedly, a deeper understanding as to why seemingly related synthetic catalysts often require very different reductant and acid combinations to be competent for $\mathrm{N}_{2} \mathrm{RR}$ is needed.

HER can occur by the background reaction between the reductant and acid; synthetic $\mathrm{N}_{2} \mathrm{RR}$ catalysts depend on limiting the rate of background HER relative to the catalytic $\mathrm{N}_{2} \mathrm{RR}$ rate. A catalyzed HER process, presumably accessible and competitive for many $\mathrm{N}_{2} \mathrm{RR}$ catalysts, can also limit the efficacy of $\mathrm{N}_{2} \mathrm{RR}$ selectivity. Both scenarios can be at play. ${ }^{4,9}$

For a complex that catalyzes both $\mathrm{N}_{2} \mathrm{RR}$ and HER, numerous pathways for the latter process are possible. $\mathrm{H}_{2}$ may evolve via protonation of a metal-bound hydride, ${ }^{3,9}$ a commonly proposed pathway for synthetic HER catalysts. Accordingly, the build-up of M-H species has been observed both during and after catalytic $\mathrm{N}_{2} \mathrm{RR}$ experiments. ${ }^{2,9,10}$ The accumulation of $\mathrm{M}-\mathrm{H}$ species is generally thought to attenuate $\mathrm{N}_{2} \mathrm{RR}$ activity, and hydride precatalysts can give rise to diminished yields for $\mathrm{N}_{2} \mathrm{RR} .{ }^{2,3,9}$ When hydride precursors serve as active precatalysts for $\mathrm{N}_{2} R R$, it is presumed they react with acid and reductant to release $\mathrm{H}_{2}$, thereby generating a species that is on-path for $\mathrm{N}_{2} \mathrm{RR} .{ }^{3,9}$ As an example of this, for a tris(phosphine)borane iron catalyst system studied extensively by our lab, $\left[\left(\mathrm{P}_{3}{ }^{\mathrm{B}}\right) \mathrm{Fe}\left(\mathrm{N}_{2}\right)\right]^{-}(\mathrm{P}$ $\left.=\sigma-\left(\mathrm{P}_{i} \mathrm{Pr}_{2}\right)_{2} \mathrm{C}_{6} \mathrm{H}_{4}\right)$, a dihydride intermediate was observed as an off-path resting state of the 
system when $\mathrm{KC}_{8}$ and $\mathrm{HBAr}_{4}{ }_{4}\left(\mathrm{Et}_{2} \mathrm{O}\right)\left(\mathrm{BAr}_{4}{ }_{4}=\right.$ tetrakis- $(3,5-$

bis(trifluoromethyl)phenyl)borate) were employed (Figure 1). ${ }^{9}$ This dihydride species can be converted to an on path intermediate by reductive protonation. ${ }^{9}$ A conceptually similar pathway has been described by Nishibayashi and coworkers for a (PNP)Fe system (Figure 1, left). ${ }^{3}$

Another possible competing HER pathway present within $\mathrm{N}_{2} \mathrm{RR}$ systems that has been considered by our lab involves a bimolecular, $\mathrm{N}_{\mathrm{x}} \mathrm{H}_{\mathrm{y}}$ ligand-mediated step wherein two $\mathrm{Fe}\left(\mathrm{N}_{\mathrm{x}} \mathrm{H}_{\mathrm{y}}\right)$ intermediates that feature weak $\mathrm{N}-\mathrm{H}$ bonds evolve $\mathrm{H}_{2}$ (Eqs. 1 and 2). ${ }^{6}$

$$
\begin{gathered}
2 \mathrm{Fe}-\mathrm{NNH} \rightarrow 2 \mathrm{Fe}-\mathrm{N}_{2}+\mathrm{H}_{2} \\
2 \mathrm{Fe}-\mathrm{NNH}_{2} \rightarrow 2 \mathrm{Fe}-\mathrm{NNH}+\mathrm{H}_{2} \quad \text { (Eq. } 1 \text { ) }
\end{gathered}
$$

Protonation at the metal versus at coordinated $\mathrm{N}_{2}$ to form a metal hydride should be thermodynamically favored, ${ }^{6}$ though the kinetic site of protonation can involve the coordinated $\mathrm{N}_{2}$ ligand. Even if protonation at $\mathrm{N}_{2}$ is kinetically favored, this can be followed by intra- or intermolecular $\mathrm{H}$-atom/hydride/proton transfer to form a metal hydride. ${ }^{11}$ Initial protonation at a site on the auxiliary ligand can also be kinetically favored. ${ }^{12}$ Protonation at the terminal nitrogen $\left(\mathrm{N}_{\beta}\right)$ is desired for selectivity towards nitrogen fixation. For the $\mathrm{P}_{3}{ }^{\mathrm{B}} \mathrm{Fe}$ system, iron is by far the thermodynamically favored site for protonation. However, the steric profile of the complex and the acids used appear to render functionalization at $\mathrm{N}_{\beta}$ kinetically favorable. ${ }^{13}$

Recently, our group reported two related iron-based complexes bearing hydride ligands, $\left.\left(\mathrm{P}_{2} \mathrm{P}^{\mathrm{Ph}}\right) \mathrm{Fe}(\mathrm{H})\right]_{2}\left(\mu-\mathrm{N}_{2}\right)(\mathbf{1})$ and $\left(\mathrm{P}_{2} \mathrm{P}^{\mathrm{Ph}}\right) \mathrm{Fe}\left(\mathrm{N}_{2}\right)(\mathrm{H})_{2}(\mathbf{2})\left(\mathrm{P}_{2} \mathrm{P}^{\mathrm{Ph}}=\right.$ bis $(o$-diisopropylphosphinophenyl)-phenylphosphine), that are modestly active systems for $\mathrm{N}_{2} \mathrm{RR}$ (Figure 1 , right). ${ }^{2}$ For complex 2, photo-induced $\mathrm{H}_{2}$ elimination was proposed to yield a more activated $\mathrm{Fe}-\mathrm{N}_{2}$ species that could undergo subsequent reductive protonation steps to generate $\mathrm{NH}_{3} . \mathrm{An} \mathrm{H}_{2}$ elimination step can also be observed for $\left(\mathrm{P}_{3} \mathrm{~B}\right)(\mu-\mathrm{H}) \mathrm{Fe}\left(\mathrm{N}_{2}\right)(\mathrm{H})$, resulting in the formation of $\left(\mathrm{P}_{3} \mathrm{~B}\right) \mathrm{Fe}\left(\mathrm{N}_{2}\right){ }^{2,14}$

Although precatalysts $\mathbf{1}$ and $\mathbf{2}$ are significantly less efficient for $\mathrm{N}_{2} \mathrm{RR}$ than $\left[\left(\mathrm{P}_{3}{ }^{\mathrm{B}}\right) \mathrm{Fe}\left(\mathrm{N}_{2}\right)\right]^{-}$ and certain other metal catalysts, they provide a fascinating model system for in-depth study because they have been shown to display substantial enhancement for $\mathrm{N}_{2} \mathrm{RR}$ under irradiation. ${ }^{2}$ Furthermore, these catalysts bear hydride ligands but are nonetheless active for $\mathrm{N}_{2} \mathrm{RR}$, affording an opportunity to investigate the role of the hydride ligands in $\mathrm{N}_{2} \mathrm{RR}$ and competing HER. Finally, a better understanding of the electronic and structural factors that influence the required redox potential for $\mathrm{N}_{2} \mathrm{RR}$ in this phosphine-iron catalyst system compared to other systems can aid in the development of selective catalysts that operate at a comparatively low net driving force. 


\section{Results and Discussion}

In our prior communication we proposed that the product of $\mathrm{H}_{2}$ elimination from wellcharacterized dihydride 2 might be " $\left(\mathrm{P}_{2} \mathrm{P} P \mathrm{Ph}\right) \mathrm{Fe}\left(\mathrm{N}_{2}\right)$ ". ${ }^{2}$ Reasoning that this or a related species might be on-path for $\mathrm{N}_{2} \mathrm{RR}$, we targeted an independent synthesis. $\left(\mathrm{P}_{2} \mathrm{P}^{\mathrm{Ph}}\right) \mathrm{FeBr}_{2}(3)$ provided a logical starting point. Treatment of $\mathbf{3}$ with 1.05 equiv sodium mercury amalgam resulted in the formation of $\left(\mathrm{P}_{2} \mathrm{P}^{\mathrm{Ph}}\right) \mathrm{FeBr}(4)$ in $65 \%$ yield (Scheme 1). 4 exhibits $C_{\mathrm{s}}$ symmetry in solution based on its ${ }^{1} \mathrm{H}$ NMR spectrum and a distorted tetrahedral geometry $\left(\tau_{4}=0.77\right)^{15}$ in the solid state (See Figure S1 and S62).

Bromide 4 is a useful synthon for several complexes of present interest. For example, treatment of $\mathbf{4}$ with $\mathrm{NaHBEt}_{3}$ in toluene at $-78^{\circ} \mathrm{C}$ provides a more favorable route to the diiron complex 1 (Scheme 1), whose preparation was previously described by $\mathrm{NaHBEt}_{3}$ reduction of $\mathbf{3}$. Furthermore, $\mathbf{4}$ can be reduced with sodium mercury amalgam in either benzene or THF to provide a new, maroon red complex $\left(\mathrm{P}_{2} \mathrm{P}^{\mathrm{Ph}}\right) \mathrm{Fe}\left(\mathrm{N}_{2}\right)_{2}(\mathbf{5}) .5$ can be alternatively prepared by reduction of $\mathbf{3}$ with excess sodium mercury amalgam in benzene (Scheme 1).

18-electron 5 exhibits two intense bands in its IR spectrum (thin film; $\nu_{\text {symm }}=2065 \mathrm{~cm}^{-1}$, $\nu_{\text {asymm }}=2005 \mathrm{~cm}^{-1}$ ) and its solid-state crystal structure (See Figure S63), reveals a distorted trigonal bipyramidal geometry at iron $\left(\tau_{5}=0.54\right)^{16}$ with Fe-P distances $\sim 0.15 \AA$ shorter than in $\mathbf{3}$, reflecting its singlet ground state. ${ }^{2}$ The structure and stretching frequencies of the five-coordinate $\mathrm{N}_{2}$ complex 5 is closely related to recently reported $\left(\mathrm{P}^{\mathrm{R}} \mathrm{PCy}{ }_{2}\right) \mathrm{Fe}\left(\mathrm{N}_{2}\right)_{2}$ $\left(\mathrm{P}^{\mathrm{R}} \mathrm{P}^{\mathrm{Cy}}{ }_{2}=\mathrm{RP}\left(\mathrm{CH}_{2} \mathrm{CH}_{2} \mathrm{PCy}_{2}\right)_{2}, \mathrm{R}=\mathrm{Ph}, \mathrm{tBu}\right)$ complexes. ${ }^{17}$ In the latter $\mathrm{N}_{2}$ complexes, facile $\mathrm{N}_{2}$ dissociation hampers their isolation. Although $\mathbf{5}$ is also susceptible to $\mathrm{N}_{2}$ dissociation (vide infra) it can be readily isolated by evaporation of the solvent in vacuo followed by extraction with pentane.

\section{$\mathrm{N}_{2}$-Binding Equilibria of 5.}

A solution equilibrium exists between $\mathbf{5}$ and a dinuclear, mono- $\mathrm{N}_{2}$-bridged complex $\mathbf{6}$ (Scheme 1). This is clearly gleaned from ${ }^{1} \mathrm{H}$ and ${ }^{31} \mathrm{P}$ NMR spectroscopies. For example, the ${ }^{1} \mathrm{H}$ NMR signal intensities for $\mathbf{5}$ decay upon degassing the solution in a J-Young NMR tube and the signals corresponding to $\mathbf{6}$ grow in (See Figure S23). Addition of $\mathrm{N}_{2}$ regenerates 5. The absence of an $\mathrm{N}_{2}$ stretch in the IR spectrum of $\mathbf{6}$, and the release of 1.5 equiv of $\mathrm{N}_{2}$ per Fe on conversion of $\mathbf{5}$ to $\mathbf{6}$, as measured by a Toepler pump experiment, are consistent with our formulation of 6 (Scheme 1; Eq. 3):

$$
2\left(\mathrm{P}_{2} \mathrm{P}^{\mathrm{Ph}}\right) \mathrm{Fe}\left(\mathrm{N}_{2}\right)_{2} \rightarrow\left\{\left(\mathrm{P}_{2} \mathrm{P}^{\mathrm{Ph}}\right) \mathrm{Fe}\right\}_{2}\left(\mu-\mathrm{N}_{2}\right)+3 / 2 \mathrm{~N}_{2} \quad \text { (Eq. 3) }
$$

Monitoring the ${ }^{1} \mathrm{H}$ and ${ }^{31} \mathrm{P}$ chemical shifts of 6 over a $130{ }^{\circ} \mathrm{C}$ range under vacuum reveals deviation from Curie-behavior (Figure 2 and S31-S33). The singlet ground state of 6 likely arises from antiferromagnetic coupling of two $S=1$ iron nuclei. The dramatic shifts in the NMR spectra are therefore attributed to partial population of triplet and quintet states separated by $2 J$ and $6 J$ from the ground state, respectively (as obtained for the Heisenberg- 
Dirac-VanVleck Hamiltonian in the notation $H_{\mathrm{HDVV}}=-2 \mathrm{~J} S_{1} S_{2}$ ). Fitting of the appropriate Boltzmann function to the experimental data yields $J=-940 \pm 9.4 \mathrm{~cm}^{-1}$ (Equation S1). ${ }^{18}$ Antiferromagnetic coupling for an $\mathrm{N}_{2}$-bridged diiron species has been observed previously. 19

\section{Increased Turnover with Non-Hydride Precatalysts and Identification of Off-Path Species.}

Previous $\mathrm{N}_{2} \mathrm{RR}$ studies using the $\left(\mathrm{P}_{2} \mathrm{P}^{\mathrm{Ph}}\right) \mathrm{Fe}$-system were performed with the hydride complexes $\mathbf{1}$ and $\mathbf{2}$ as (pre)catalysts. We wondered whether increased turnover numbers might be realized with $\left(\mathrm{P}_{2} \mathrm{P}^{\mathrm{Ph}}\right) \mathrm{Fe}\left(\mathrm{N}_{2}\right)_{2}, \mathbf{5}$, devoid of hydride ligands. Indeed, catalysis under the same conditions with $\mathbf{5}$ resulted in significantly higher $\mathrm{NH}_{3}$ yields than those afforded by 1 and 2. For example, at a loading of 150 equivalents acid and 180 equivalents reductant at $-78{ }^{\circ} \mathrm{C}$ in $\mathrm{Et}_{2} \mathrm{O}$, in the absence of light, complexes $\mathbf{1}$ and $\mathbf{2}$ catalyzed only $3.6 \pm 0.6$ and 2.6 \pm 0.01 equiv $\mathrm{NH}_{3}$ per iron, respectively, whereas 5 catalyzed the generation of $6 \pm 0.5$ equiv. Interestingly, a comparable $\mathrm{NH}_{3}$ yield $(5.1 \pm 0.02$ equiv per iron center) could be realized with 5 using only $1 / 3$ as much reductant and acid (50 equiv $\operatorname{HBAr}_{4}{ }_{4}\left(\mathrm{Et}_{2} \mathrm{O}\right)$ and 60 equiv $\mathrm{KC}_{8}$ ), which was not the case for either $\mathbf{1}$ or $\mathbf{2}$. A possible explanation for this difference is that HER catalysis from the hydrides, which are present in the highest concentration at the onset of runs with $\mathbf{1}$ and $\mathbf{2}$, outcompetes $\mathrm{N}_{2} \mathrm{RR}$.

Similar $\mathrm{NH}_{3}$ yields were obtained for the three different precatalysts $\mathbf{1}, \mathbf{2}$, and $\mathbf{5}$ in catalytic experiments irradiated with a mercury lamp. We presume that dihydride $\mathbf{2}$ releases $\mathrm{H}_{2}$ upon irradiation with light to yield $\mathbf{5}$, and that this transformation occurs rapidly under turn-over conditions as all (pre)catalysts give similar yields. The consumption of hydride species via photolysis reduces HER catalyzed by the hydrides, thus increasing overall efficiency for $\mathrm{NH}_{3}$.

To determine whether catalyzed HER contributes to the low yields of $\mathrm{NH}_{3}$ obtained with dihydride $\mathbf{2}$, hydrogen evolution was measured under catalytically relevant conditions. As shown in Figure 3, the initial rate of $\mathrm{H}_{2}$ evolution at $-78^{\circ} \mathrm{C}$, is significantly enhanced by the presence of either $\mathbf{2}$ or $\mathbf{5}$. These data suggests both $\mathbf{2}$ and $\mathbf{5}$ are comparatively competent catalysts for HER, whereas complex $\mathbf{5}$ is a more effective (pre)catalyst for $\mathrm{N}_{2} \mathrm{RR}$. Indeed, the fact that most of the acid is consumed within 30 minutes at $-78{ }^{\circ} \mathrm{C}$ speaks to how rapidly 5 must catalyze $\mathrm{NH}_{3}$ production for $\mathrm{N}_{2} \mathrm{RR}$ to be kinetically competitive.

Additional evidence for the active role of $\mathbf{2}$ in HER is obtained from Mossbauer studies of freeze-quenched samples. Freeze-quenching of a catalytic run using ${ }^{57} \mathrm{Fe}$-labeled 2, 50 equiv acid, and 60 equiv reductant, shows its disappearance within 5 minutes (Figure 4, middle trace). A new broad feature, likely due to the overlap of several species, is observed. Freezequenching the reaction after 30 minutes provides a similarly broad signal (Figure 4, bottom trace), but one that also contains $\mathbf{2}$, with its characteristic small quadrupole splitting (constituting $\sim 40 \%$ of the total). Experiments using 5 as the precatalyst provide an analogously broad signal after 5 and 30 minutes (See Figure S59-S60). Notably, dihydride 2 is always observed at the end of a catalytic experiment, once the sample has been warmed to room temperature. It is the major species present (typically 90\% by Mössbauer spectroscopy). Furthermore, IR and NMR spectra recorded after runs using $\mathbf{5}$ as the 
precatalyst show $\mathbf{2}$ as the only identifiable species upon warming. These data collectively suggest that the catalytic system converts to a Fe-H species (2), which is on path for HER (vide infra), as the major product. ${ }^{2}$ This finding is similar to that of $\left[\left(\mathrm{P}_{3}{ }^{\mathrm{B}}\right) \mathrm{Fe}\left(\mathrm{N}_{2}\right)\right]^{-}$, which also ends tied-up in an off-path hydride-borohydride state (Figure 1, left). ${ }^{9}$

\section{Oxidative addition and reductive elimination of $\mathrm{H}_{2}$.}

To investigate potential pathways by which hydride species form during catalysis, stoichiometric reactions were performed with dihydride $\mathbf{2}$, the bis- $\mathrm{N}_{2}$ complex $\mathbf{5}$, and dinuclear 6. Addition of $\mathrm{H}_{2}$ to $\mathbf{5}$ (or 6), followed by $\mathrm{N}_{2}$, resulted in the quantitative formation of $\mathbf{2}$ (Scheme 2). However, addition of $\mathrm{H}_{2}$ to $\mathbf{5}$ at $-78{ }^{\circ} \mathrm{C}$ in a J-Young tube for one hour resulted in the appearance of a trace amount of $\mathbf{2}$. Full conversion was only observed upon warming to room temperature (see Figure S25). The latter result strongly suggests that the formation of 2 under the catalytic conditions at $-78{ }^{\circ} \mathrm{C}$ does not occur by a reaction between 5 and $\mathrm{H}_{2}$.

Irradiating solutions of 2 with a $100 \mathrm{~W}$ mercury lamp at $-78{ }^{\circ} \mathrm{C}$ or room temperature results in darkening of the solution and the formation of $\mathbf{5}$ (Scheme 2). Complete disappearance of 2 is not observed, suggesting the reaction is reversible (Figure S27). A possible 16-electron intermediate, such as " $\left(\mathrm{P}_{2} \mathrm{P}^{\mathrm{Ph}}\right) \mathrm{Fe}\left(\mathrm{N}_{2}\right)$ ", ${ }^{2}$ could not be identified by NMR, IR, or Mössbauer spectroscopy.

$\mathrm{H}_{2}$ elimination from $\mathbf{2}$ to 5 leads to a significant decrease in $v(\mathrm{NN})$ stretching frequencies due to increased backbonding upon $\mathrm{H}_{2}$ elimination. A similar effect was observed previously for $\left(\mathrm{P}_{3}{ }^{\mathrm{B}}\right)(\mu-\mathrm{H}) \mathrm{Fe}\left(\mathrm{N}_{2}\right)(\mathrm{H}) .^{2}$ In this context, these systems crudely model a proposed $\mathrm{N}_{2}$ binding/activation via $\mathrm{H}_{2}$ elimination at the $\mathrm{E}_{4}$ state of the iron-molybdenum cofactor (Figure 5). ${ }^{20}$ Clearly, increased $\mathrm{N}_{2}$ activation upon $\mathrm{H}_{2}$ elimination observed for this $\mathrm{P}_{2} \mathrm{P}^{\mathrm{Ph}} \mathrm{Fe}$-system would be even more pronounced for the unobserved, but perhaps catalytically relevant mono- $\mathrm{N}_{2}$ adduct " $\mathrm{P}_{2} \mathrm{P}^{\mathrm{Ph}} \mathrm{Fe}\left(\mathrm{N}_{2}\right)$ " ( vide infra).

\section{Stoichiometric reactivity and hydrogen evolution.}

To further probe HER catalysis by the present system, $\mathrm{HBAr}_{4}$ was added to $\left(\mathrm{P}_{2} \mathrm{P}^{\mathrm{Ph}}\right) \mathrm{Fe}\left(\mathrm{N}_{2}\right)_{2}$ 5 at $-78{ }^{\circ} \mathrm{C}$, causing a color change from maroon to dark yellow upon warming. The product of protonation at iron was identified as $\left[\left(\mathrm{P}_{2} \mathrm{P}^{\mathrm{Ph}}\right) \mathrm{Fe}\left(\mathrm{N}_{2}\right)_{2}(\mathrm{H})\right]\left[\mathrm{BAr}{ }_{4}\right]$ (7) (Scheme 3), featuring a diagnostic ${ }^{1} \mathrm{H}$ NMR hydride resonance (-17 ppm) and bands at 2069, 2194 and $2264 \mathrm{~cm}^{-1}$, corresponding to the $\nu(\mathrm{Fe}-\mathrm{H})$ and $\nu(\mathrm{NN})$ IR stretches. Its solid-state structure was also determined (see Figure S64). This complex can also be obtained by oxidation of $\left\{\left(\mathrm{P}_{2} \mathrm{P}^{\mathrm{Ph}}\right) \mathrm{Fe}(\mathrm{H})\right\}_{2}\left(\mu-\mathrm{N}_{2}\right) 1$ with either $\mathrm{FcBAr}_{4}\left(\mathrm{Fc}=\right.$ bis $\left(\eta_{5}\right.$-cyclopentadienyl)iron) or $\operatorname{HBAr}_{4}{ }_{4}$ (Scheme 3). Of primary interest, protonation of 2 with $\operatorname{HBAr}_{4}$ likewise generates 7 with concomitant $\mathrm{H}_{2}$ release, possibly via an " $\left[\mathrm{Fe}\left(\mathrm{H}_{2}\right)(\mathrm{H})\right]^{+}$" adduct. ${ }^{21}$

Monohydride 7 can be cleanly reduced to dinuclear 1 using either $\mathrm{Cp}_{2}{ }_{2} \mathrm{Co}$ or stoichiometric $\mathrm{KC}_{8}$. Reduction of $\mathbf{7}$ with an excess of $\mathrm{KC}_{8}$ by contrast generates a different diamagnetic species which, following addition of 18-crown-6, could be isolated in pure form as $\left[\mathrm{P}_{2} \mathrm{P}^{\mathrm{Ph}} \mathrm{Fe}\left(\mathrm{N}_{2}\right)(\mathrm{H})\right][\mathrm{K}(18$-crown-6)] (8) (Scheme 3). Complex 8 features a diagnostic hydride resonance in its ${ }^{1} \mathrm{H}$ NMR spectrum $(\delta=-9.69 \mathrm{ppm}, \mathrm{dt})$, and its solid-state structure displays 
a short Fe-N (1.774(1) $\mathrm{A})$ and an elongated N-N (1.139(2) $\mathrm{A})$ bond. A high degree of activation of $\mathrm{N}_{2}$ is reflected by its $\nu(\mathrm{NN})\left(1924 \mathrm{~cm}^{-1}\right)$.

Stoichiometric mixing of cation $\mathbf{7}$ and anion $\mathbf{8}$ resulted in comproportionation to $\mathbf{1}(>90 \%$ yield). Proton transfer (PT) from $\mathbf{7}$ to $\mathbf{8}$ might have alternatively resulted in the formation of 2 and $\mathbf{5}$ (Scheme 4), but this was not observed. This may be rationalized by low acidity of the hydride ligand in $\mathbf{7}$, which is not deprotonated by $\mathrm{NaO} t \mathrm{Bu}$. Relatedly, $\mathbf{8}$ is weakly basic and is not protonated by $\mathrm{MeOH}$ at $-78{ }^{\circ} \mathrm{C}$. The absence of proton transfer between $\mathbf{7}$ and $\mathbf{8}$ makes this an unlikely step for (re)generating $\mathbf{2}$ and $\mathbf{5}$ under turnover conditions. Dihydride $\mathbf{2}$ can, however, be obtained readily by protonation of $\mathbf{8}$ with $\operatorname{HBAr}_{4}$ at low temperature (Scheme 4).

Apparent differences in reactivity of the hydrides with respect to $\mathrm{N}_{2} \mathrm{RR}$ can be rationalized by the availability, or lack of, kinetically competent pathways for the hydrides to be converted to on-path $\mathrm{Fe}-\mathrm{N}_{2}$ species at $-78^{\circ} \mathrm{C}$. For the $\mathrm{P}_{2} \mathrm{P}^{\mathrm{Ph}}$ system, no pathway has been identified via which hydrides convert back to on-path $\mathrm{Fe}-\mathrm{N}_{2}$ species. Instead, in stoichiometric reactions, the different hydrides interconvert in an HER cycle (Figure 6). However, the observation of $\mathrm{NH}_{3}$ production during catalytic experiments with $\mathbf{1}$ or $\mathbf{2}$ as precatalysts indicates that there must be some pathway to a species active for $\mathrm{N}_{2} \mathrm{RR}$, even if comparatively inefficient.

\section{Reduction of $\left(\mathrm{P}_{2} \mathrm{PPh}\right) \mathrm{Fe}\left(\mathrm{N}_{2}\right)_{2}$.}

The fact that there is no reactivity between 5 and $\mathrm{HBAr}^{\mathrm{F}} 4$ at $-78{ }^{\circ} \mathrm{C}$ indicates that the $\mathrm{N}_{2}$ ligands are not sufficiently activated to be protonated, in accord with comparatively high $\mathrm{N}_{2}$ stretching frequencies for 5 (2065 and $2009 \mathrm{~cm}^{-1}$ ). To explore whether further reduction might generate a more reactive and hence on-path species, 5 was stirred with 1 equiv potassium naphthalide followed by the addition of 18-crown-6. This produced the anionic, 4-coordinate $S=1 / 2\left(\underline{\mu}_{\mathrm{eff}}=1.80\right)$ complex $\left[\left(\mathrm{P}_{2} \mathrm{P}^{\mathrm{Ph}}\right) \mathrm{Fe}\left(\mathrm{N}_{2}\right)\right][\mathrm{K}(18$-crown-6)] (9) (Scheme 5). 9 features a single and highly activated $\mathrm{N}_{2}$ ligand $\left(1872 \mathrm{~cm}^{-1}\right)$. Its solid-state crystal structure shows a disordered tetrahedral iron center $\left(\tau_{4}=0.75\right)$, and $\mathrm{CV}$ measurements show a quasireversible $\mathrm{Fe}^{0 /-}$ redox event centered at $-2.5 \mathrm{~V}$ vs Fc/Fc ${ }^{+}$(Figure 7). At more negative potential, an irreversible, presumably $\mathrm{Fe}^{-2 /-1}$ redox event is observed.

Reduction of 5 with an excess of $\mathrm{KC}_{8}$ produced a diamagnetic species $\left({ }^{31} \mathrm{P}\right.$ NMR: $\delta=$ 113.13, doublet; $95.15 \mathrm{ppm}$, triplet) identified as $\left[\left(\mathrm{P}_{2} \mathrm{P}^{\mathrm{Ph}}\right) \mathrm{Fe}\left(\mathrm{N}_{2}\right)\right]\left[\mathrm{K}_{2}(\mathrm{THF})_{3}\right]$ (10) (Scheme 5). Complex 10 is an unusual iron species in that it is isoelectronic with $\left[\mathrm{Fe}(\mathrm{CO})_{4}\right]^{2-}$ (vide infra). ${ }^{22,23} \mathrm{~A}{ }^{15} \mathrm{~N}$-labeled analogue was synthesized by reduction of $\left(\mathrm{P}_{2} \mathrm{P}^{\mathrm{Ph}}\right) \mathrm{FeBr}_{2}$ under ${ }^{15} \mathrm{~N}_{2}$; its ${ }^{15} \mathrm{~N}$ NMR spectrum (2.36 and $\left.-26.23 \mathrm{ppm}\right)$ rules out the possibility of a dinuclear structure $\left[\left\{\left(\mathrm{P}_{2} \mathrm{P}^{\mathrm{Ph}}\right) \mathrm{Fe}\right\}_{2}\left(\mu-\mathrm{N}_{2}\right)\right] \mathrm{K}_{2} \cdot{ }^{24}$ Consistent with our assignment of dianion 10, its IR spectrum displays a $v(\mathrm{NN})$ at $1677 \mathrm{~cm}^{-1}\left(1591 \mathrm{~cm}^{-1}\right.$ for $\left.\mathbf{1 0}-{ }^{15} \mathrm{~N}_{2}\right)$ that is broadened due to ion-pairing, consistent with a very strongly activated $\mathrm{N}_{2}$ ligand. Addition of 18-crown- 6 resulted in intractable decomposition, suggesting tight ion-pairing is important to its stability. ${ }^{25}$

The structure of $\mathbf{1 0}$ in the solid-state (Figure 7) presents two distorted tetrahedral iron centers $\left(\tau_{4}=0.71\right)$ that are related by an inversion center within a dimeric unit. Tight ion 
pairing is evident from the close proximity of each iron center to the potassium cations ( $\mathrm{Fe}-$ $\mathrm{K}=3.442$ and $3.567 \AA$ ); each $\mathrm{N}_{2}$ ligand interacts with three potassium ions. The $\mathrm{Fe}-\mathrm{N}$ bond is remarkably short $(1.728(2) \AA), \sim 0.1 \AA$ shorter than the Fe-N bonds in $\mathbf{5}$, reflective of very strong backbonding. Relatedly, significant $\mathrm{N}-\mathrm{N}$ elongation is also observed (1.189(3) $\AA$ ). The Fe-P bond distances are also highly contracted at 2.1494(6) $\AA$, in line with the very strong covalency expected of a $\mathrm{d}^{10}$ tetrahedral iron center. Prior to this study, tetrahedral $\mathrm{Fe}$ -II species have been limited to complexes with very strong pi-acceptor ligands, such as $\mathrm{CO}$, ${ }^{22,23} \mathrm{PF}_{3},{ }^{26}\left(\mathrm{C}_{2} \mathrm{H}_{4}\right),{ }^{27,28}$ (COD) (COD = cyclooctadiene), ${ }^{27}$ and $\mathrm{CNAr}^{25,29}$ Additional species bearing phosphorine ${ }^{30}$ and nitrosyl ${ }^{31}$ ligands have also been reported, however the assignment of their oxidation state is ambiguous.

The Mössbauer spectrum of a perfectly tetrahedral $\mathrm{d}^{10}$ iron complex, such as $\mathrm{Na}_{2}\left[\mathrm{Fe}(\mathrm{CO})_{4}\right]$, should show a singlet instead of a quadrupole doublet due to the spherical electric field gradient at the iron nucleus; ${ }^{22,32}$ any quadrupole splitting in $\mathrm{Na}_{2}\left[\mathrm{Fe}(\mathrm{CO})_{4}\right]$ is barely discernable. ${ }^{32}$ Similarly, the Mössbauer spectrum of $\mathbf{1 0}$ shows an apparent singlet (Figure 7) which can be fit by a small quadrupole splitting $\left(\delta=0.27 \mathrm{~mm} / \mathrm{s}, \Delta \mathrm{E}_{\mathrm{Q}}=0.26 \mathrm{~mm} / \mathrm{s}\right)$. The very small quadrupole splitting in $\mathbf{1 0}$, which is required to have at least a modest electric field gradient owing to the presence of three unique types of donor ligands, indicates its classification as a $\mathrm{d}^{10}$ tetrahedral structure is appropriate, at least to the extent this description is apt for $\mathrm{Na}_{2}\left[\mathrm{Fe}(\mathrm{CO})_{4}\right]$ given the significant covalency in both species.

\section{Functionalization of formal $\mathrm{Fe}^{-\mathrm{I}}$ and $\mathrm{Fe}^{-\mathrm{Il}}$ species.}

Current examples of Fe-mediated $\mathrm{N}_{2} \mathrm{RR}$ are thought to proceed through $\mathrm{Fe}-\mathrm{N}_{2}$ intermediates with $v(\mathrm{NN})$ stretching frequencies below $1970 \mathrm{~cm}^{-1}$. 1d,3,33 The $\mathrm{N}_{2}$ ligand of $\left[\left(\mathrm{P}_{2} \mathrm{P}^{\mathrm{Ph}}\right) \mathrm{Fe}\left(\mathrm{N}_{2}\right)\right]\left[\mathrm{K}(18\right.$-crown-6) $](9)$ has a stretching frequency of $1872 \mathrm{~cm}^{-1}$ and in this context should be activated enough to be functionalized. Attempts to protonate 9 with stoichiometric $\mathrm{HBAr}_{4} \mathrm{~F}_{4}$ unfortunately resulted in complex product mixtures. Silylium ions $\left(\mathrm{R}_{3} \mathrm{Si}^{+}\right)$have been used as surrogate electrophiles for protons to model unstable protonated Fe- $\mathrm{N}_{\mathrm{x}} \mathrm{H}_{\mathrm{y}}$ species. ${ }^{1 \mathrm{c}, 34-38}$ Reacting 10, generated in situ, with one equivalent of $\mathrm{Me}_{3} \mathrm{SiCl}$ at $-78{ }^{\circ} \mathrm{C}$, results in an immediate color change from dark purple to dark orange. After workup, diamagnetic $\left[\left(\mathrm{P}_{2} \mathrm{P}^{\mathrm{Ph}}\right) \mathrm{Fe}\left(\mathrm{NNSiMe}_{3}\right)\right] \mathrm{K}\left(\left[11-\mathrm{NNSiMe}_{3}\right]^{-}\right)$was isolated as a dark brown solid in 50\% yield (Scheme 6). As for 10, a tight ion-pair seems to be important for its stability; addition of 18-crown-6 results in its decomposition. The solid-state structure of $\left[11-\mathrm{NNSiMe}_{3}\right]^{-}$reveals a four-coordinate iron center with a distorted tetrahedral geometry $\left(\tau_{4}=0.76\right)$. The $\mathrm{Fe}-\mathrm{N}$ bond length of $\left[\mathbf{1 1}-\mathrm{NNSiMe}_{3}\right]^{-}$is even shorter than that in $\mathbf{1 0}$ (1.664(7) $\AA$ vs. 1.728(2) ̊̊ respectively), and the $\mathrm{N}-\mathrm{N}$ bond length is much longer (1.270(9) $\AA$ vs. $1.189(3) \AA$ ) in $\mathbf{1 0}$.

Attempts to oxidize $\left[11-\mathrm{NNSiMe}_{3}\right]^{-}$at $-78{ }^{\circ} \mathrm{C}$ with cobaltocenium to generate the neutral diazenido species $\left(\mathrm{P}_{2} \mathrm{P}^{\mathrm{Ph}}\right) \mathrm{Fe}-\mathrm{NNSiMe}{ }_{3}$ resulted in a mixture of species, presumably complicated by the loss of $\mathrm{Me}_{3} \mathrm{Si}$. Based on low temperature EPR data (Figure 8), we assign the major product of oxidation to be the iron-silyl complex $\left(\mathrm{P}_{2} \mathrm{P}^{\mathrm{Ph}}\right) \mathrm{Fe}\left(\mathrm{SiMe}_{3}\right)\left(\mathrm{N}_{2}\right)$ (its EPR signature is highly similar to that of $\left(\mathrm{P}_{2} \mathrm{P}^{\mathrm{Ph}}\right) \mathrm{Fe}\left(\mathrm{N}_{2}\right)(\mathrm{H}) ;{ }^{2}$ see Figure 8$)$. There is also a minor component in the EPR trace that can be tentatively assigned as the expected diazenido $\left(\mathrm{P}_{2} \mathrm{P}^{\mathrm{Ph}}\right) \mathrm{Fe}\left(\mathrm{NNSiMe}_{3}\right)$. Use of ${ }^{i} \mathrm{Pr}_{3} \mathrm{SiOTf}$ instead leads to the analogous [11-NNSi $\left.\mathrm{Pr}_{3}\right]^{-}$ 
complex, but in this case its oxidation affords a clean EPR spectrum consistent with the diazenido species 12-NNSi ${ }^{i} \mathrm{Pr}_{3}$ (Figure 8). Addition of ${ }^{i} \mathrm{Pr}_{3} \mathrm{SiOTf}$ to $\left[\left(\mathrm{P}_{2} \mathrm{P}^{\mathrm{Ph}}\right) \mathrm{Fe}\left(\mathrm{N}_{2}\right)\right]^{-} 9$ generates the same species as is evident by IR and EPR spectroscopy (Figure 8). The IR spectrum of 12-NNSi ${ }^{i} \mathrm{Pr}_{3}$ displays an intense band corresponding to $v \mathrm{NN}$ at $1660 \mathrm{~cm}^{-1}$, characteristic of iron diazenido species. ${ }^{34,37,39}$ In contrast with the $-\mathrm{SiMe}_{3}$ derivative, the $\mathrm{Si}^{i} \mathrm{Pr}_{3}$ species is stable for days. We suspect that for the less bulky $-\mathrm{SiMe}_{3}$ derivative, kinetically competitive N-to-Fe silyl migration is operative.

We intuit that $\mathbf{9}$, or its further reduced state $\left[\left(\mathrm{P}_{2} \mathrm{P}^{\mathrm{Ph}}\right) \mathrm{Fe}\left(\mathrm{N}_{2}\right)\right]^{2-} \mathbf{1 0}$, must be reached before nitrogen functionalization occurs via protonation or silylation. The iron centers in $\mathbf{9}$ and $\mathbf{1 0}$ are exposed, and are therefore susceptible to direct protonation at iron, or to facile migration from N-to-Fe. An N-protonated form of $\mathbf{9}$ (or 10) can presumably react further under the catalytic conditions to produce $\mathrm{NH}_{3}$, when both excess acid and reductant are present. Such reactivity must be kinetically competitive with a step that produces an off-path hydride.

The need to access an anionic state of the system (either $\mathbf{9}$ or 10) before functionalization at $\mathrm{N}_{2}$ can occur sets the requirement of a potent reductant for $\mathrm{N}_{2} \mathrm{RR}$ in the $\mathrm{P}_{2} \mathrm{P}^{\mathrm{Ph}} \mathrm{Fe}$-system. The $\mathrm{Fe}^{-\mathrm{I} / 0}$ couple of 9 is $-2.47 \mathrm{~V}$ vs. $\mathrm{Fc} / \mathrm{Fc}^{+}$, which is $\sim 0.30 \mathrm{~V}$ more negative than the corresponding $\mathrm{Fe}^{-\mathrm{I} / 0}$ couple for $\left[\left(\mathrm{P}_{3}^{\mathrm{B}}\right) \mathrm{Fe}\left(\mathrm{N}_{2}\right)\right]^{0 /-} ; \mathrm{N}_{2} \mathrm{RR}$ can be driven rather efficiently with the latter system using $\mathrm{Cp}_{2}{ }_{2} \mathrm{Co}$ paired with anilinium acids, which are ineffective with this precatalyst. $^{4,5}$

\section{Conclusions}

The present study highlights the detrimental effect of hydride ligands on an iron-catalyzed $\mathrm{N}_{2} \mathrm{RR}$ model system whose efficiency is enhanced by irradiation. Stoichiometric reactivity as well as freeze-quench Mossbauer studies reveal that off-path $\left(\mathrm{P}_{2} \mathrm{P}^{\mathrm{Ph}}\right) \mathrm{Fe}\left(\mathrm{N}_{2}\right)_{\mathrm{x}}(\mathrm{H})_{\mathrm{y}}$ species are formed but are not inert resting states. On the contrary, they rapidly produce hydrogen in an HER cycle operating parallel to the desired $\mathrm{N}_{2} \mathrm{RR}$ cycle. In the absence of light, these pathways compete with one another but operate along different cycles. Irradiation of $\left(\mathrm{P}_{2} \mathrm{P}^{\mathrm{Ph}}\right) \mathrm{Fe}\left(\mathrm{N}_{2}\right)(\mathrm{H})_{2} 2$ results in photoinduced $\mathrm{H}_{2}$ elimination and the formation of $\left(\mathrm{P}_{2} \mathrm{P}^{\mathrm{Ph}}\right) \mathrm{Fe}\left(\mathrm{N}_{2}\right)_{2}(\mathbf{5})$, which is significantly more competent for $\mathrm{N}_{2} \mathrm{RR}$. Thus, photolysis shifts the speciation from favoring an unproductive HER cycle to one where $\mathrm{N}_{2} \mathrm{RR}$ becomes kinetically competitive.

A deeper understanding of the required driving force for $\mathrm{N}_{2}$ functionalization is obtained by stoichiometric reactions with $\mathrm{Fe}-\mathrm{N}_{2}$ species. No protonation reactivity is observed with a strong acid for $\left(\mathrm{P}_{2} \mathrm{P}^{\mathrm{Ph}}\right) \mathrm{Fe}\left(\mathrm{N}_{2}\right)_{2}$ at $-78^{\circ} \mathrm{C}$; further reduction is required before functionalization can take place. Protonation experiments with the $\mathrm{Fe}^{-\mathrm{I}}$ and $\mathrm{Fe}^{-\mathrm{II}}$ species 9 and $\mathbf{1 0}$ provide complex mixtures, but silylation experiments are informative.

The need to access an anionic or a dianionic state of the system before productive functionalization at $\mathrm{N}_{2}$ occurs sets the low reduction potential required for $\mathrm{N}_{2} \mathrm{RR}$ by this $\mathrm{P}_{2} \mathrm{P}^{\mathrm{Ph}} \mathrm{Fe}$-system and explains why comparatively milder reductants such as $\mathrm{Cp}_{2}{ }_{2} \mathrm{Co}$, which are effective for a related $\left(\mathrm{P}_{3}{ }^{\mathrm{B}}\right) \mathrm{Fe}$-catalyst system, are ineffective in the present case. Future 
catalyst designs for iron systems should focus on anodically shifting the needed redox couple to generate an $\mathrm{Fe}-\mathrm{N}_{2}$ species while maintaining a strongly activated $\mathrm{N}_{2}$ ligand.

\section{Supplementary Material}

Refer to Web version on PubMed Central for supplementary material.

\section{ACKNOWLEDGMENT}

Dr. Michael Takase, Larry Henling and Dr. Marcus Drover are acknowledged for their assistance with crystallographic studies. Dr. Niklas Thompson is thanked for assisting with fitting the variable temperature NMR data.

Funding Sources

We are grateful to the NIH (GM-075757) for support of this research, and also to the National Science Foundation for support of the Caltech EPR Facility via the NSF-MRI grant NSF-153194, and to the Dow Next Generation Educator Fund. D.J.S acknowledges the support of the Resnick Sustainability Institute at Caltech for a Graduate Fellowship.

\section{REFERENCES}

1 (a). Yandulov DV; Schrock RR Catalytic reduction of dinitrogen to ammonia at a single molybdenum center. Science 2003, 301, 76-79. [PubMed: 12843387] (b)Arashiba K; Miyake Y; Nishibayashi Y A molybdenum complex bearing PNP-type pincer ligands leads to the catalytic reduction of dinitrogen into ammonia. Nat. Chem 2011, 3, 120-125. [PubMed: 21258384] (c)Anderson JS; Rittle J; Peters JC Catalytic conversion of nitrogen to ammonia by an iron model complex. Nature 2013, 501, 84-87. [PubMed: 24005414] (d)Hill PJ; Doyle LR; Crawford AD; Myers WK; Ashley AE Selective catalytic reduction of $\mathrm{N}_{2}$ to $\mathrm{N}_{2} \mathrm{H}_{4}$ by a simple Fe complex. J. Am. Chem. Soc 2016, 138, 13521-13524. [PubMed: 27700079] (e)Sekiguchi Y; Arashiba K; Tanaka H; Eizawa A; Nakajima K; Yoshizawa K; Nishibayashi Y Catalytic reduction of molecular dinitrogen to ammonia and hydrazine using vanadium complexes. Angew. Chem. Int. Ed 2018, 57, 9064-9068.(f)Doyle LR; Wooles AJ; Jenkins LC; Tuna F; McInnes EJL; Liddle ST Catalytic dinitrogen reduction to ammonia at a triamidoamine-titanium complex. Angew. Chem. Int. Ed 2018, 57, 6314-6318.

2. Buscagan TM; Oyala PH; Peters $\mathrm{JC} \mathrm{N}_{2}$-to- $\mathrm{NH}_{3}$ Conversion by a triphos-iron catalyst and enhanced turnover under photolysis. Angew. Chem. Int. Ed 2017, 56, 6921-6926.

3. Sekiguchi Y; Kuriyama S; Eizawa A; Arashiba K; Nakajima K; Nishibayashi Y Synthesis and reactivity of iron-dinitrogen complexes bearing anionic methyl- and phenyl-substituted pyrrolebased PNP-type pincer ligands toward catalytic nitrogen fixation. Chem. Commun 2017, 53, 12040 12043.

4. Chalkley MJ; Del Castillo TJ; Matson BD; Roddy JP; Peters JC Catalytic $\mathrm{N}_{2}$-to- $\mathrm{NH}_{3}$ Ccnversion by Fe at lower driving force: A proposed role for metallocene-mediated PCET. ACS Cent. Sci 2017, 3, 217-223. [PubMed: 28386599]

5. Chalkley MJ; Castillo T. J. Del; Matson BD; Peters JC Fe-mediated nitrogen fixation with a metallocene mediator: Exploring $\mathrm{pK}_{\mathrm{a}}$ effects and demonstrating electrocatalysis. J. Am. Chem. Soc 2018, 140, 6122-6129. [PubMed: 29669205]

6. Matson BD; Peters JC Fe-mediated HER vs N2RR: Exploring factors that contribute to selectivity in P3EFe(N2) (E = B, Si, C) catalyst model systems. ACS Catal 2018, 8, 1448-1455. [PubMed: 30555733]

7. Simpson FB; Burris RH A nitrogen pressure of 50 atmospheres does not prevent evolution of hydrogen by nitrogenase. Science 1984, 224, 1095-1097. [PubMed: 6585956]

8. Schubert KR; Evans HJ Hydrogen evolution: A major factor affecting the efficiency of nitrogen fixation in nodulated symbionts. Proc. Natl. Acad. Sci 1976, 73, 1207-1211. [PubMed: 16592307] 
9. Del Castillo TJ; Thompson NB; Peters JC A synthetic single-site Fe nitrogenase: High turnover, freeze-quench 57Fe Mössbauer data, and a hydride resting state. J. Am. Chem. Soc 2016, 138, 5341-5350. [PubMed: 27026402]

10 (a). Fajardo J; Peters JC Catalytic nitrogen-to-ammonia conversion by osmium and ruthenium complexes. J. Am. Chem. Soc 2017, 139, 16105-16108. [PubMed: 29073760] (b)Kuriyama S; Arashiba K; Nakajima K; Matsuo Y; Tanaka H; Ishii K; Yoshizawa K; Nishibayashi Y Catalytic transformation of dinitrogen into ammonia and hydrazine by iron-dinitrogen complexes bearing pincer ligand. Nat. Commun 2016, 7, 12181. [PubMed: 27435503] (c)Kuriyama S; Arashiba K; Tanaka H; Matsuo Y; Nakajima K; Yoshizawa K; Nishibayashi Y Direct transformation of molecular dinitrogen into ammonia catalyzed by cobalt dinitrogen complexes bearing anionic PNP pincer ligands. Angew. Chem. Int. Ed 2016, 55, 14291-14295.(d)Creutz SE; Peters JC Catalytic reduction of $\mathrm{N}_{2}$ to $\mathrm{NH}_{3}$ by an $\mathrm{Fe}-\mathrm{N}_{2}$ complex featuring a C-atom anchor. J. Am. Chem. Soc 2014, 136, 1105-1115. [PubMed: 24350667]

11 (a). Yandulov DV; Schrock RR; Rheingold AL; Ceccarelli C; Davis WM Synthesis and reactions of molybdenum triamidoamine complexes containing hexaisopropylterphenyl substituents. Inorg. Chem 2003, 42, 796-813. [PubMed: 12562193] (b)Yandulov DV; Schrock RR Studies relevant to catalytic reduction of dinitrogen to ammonia by molybdenum triamidoamine complexes. Inorg. Chem 2005, 44, 1103-1117. [PubMed: 15859292]

12. Kinney RA; McNaughton RL; Chin JM; Schrock RR; Hoffman BM Protonation of the dinitrogenreduction catalyst [HIPTN3N]MoIII investigated by ENDOR spectroscopy. Inorg. Chem 2011, 50, 418-420. [PubMed: 21155580]

13. Anderson JS; Cutsail GE; Rittle J; Connor BA; Gunderson W; Zhang L; Hoffman BM; Peters JC Characterization of an $\mathrm{Fe} \equiv \mathrm{N}-\mathrm{NH}_{2}$ intermediate relevant to catalytic $\mathrm{N}_{2}$ reduction to $\mathrm{NH}_{3}$. J. Am. Chem. Soc 2015, 137, 7803-7809. [PubMed: 26000443]

14. (a)Other molecular $\mathrm{Fe}(\mathrm{H}) \mathrm{x}$ complexes undergo photoinduced reductive $\mathrm{H} 2$ elimination with associated N2 binding. See: Sacco A; Aresta M Nitrogen fixation: Hydrido- and hydrido-nitrogencomplexes of Iron(II). Chem. Commun 1968, 1223-1224.(b)Whittlesey MK; Mawby RJ; Osman R; Perutz RN; Field LD; Wilkinson MP; George MW Transient and matrix photochemistry of $\mathrm{Fe}(\mathrm{dmpe}) 2 \mathrm{H} 2(\mathrm{dmpe}=\mathrm{Me} 2 \mathrm{PCH} 2 \mathrm{CH} 2 \mathrm{Me} 2)$ : dynamics of $\mathrm{C}-\mathrm{H}$ and $\mathrm{H}-\mathrm{H}$ activation J. Am. Chem. Soc 1993, 115, 8627-8637.(c)Perutz RN; Procacci B Photochemistry of Transition Metal Hydrides, Chem. Rev 2016, 116, 8506-8544. [PubMed: 27380829]

15. Okuniewski A; Rosiak D; Chojnacki J; Becker B Coordination polymers and molecular structures among complexes of mercury(II) halides with selected 1-benzoylthioureas. Polyhedron 2015, 90, 47-57.

16. Addison AW; Rao TN; Reedijk J; van Rijn J; Verschoor GC Synthesis, structure, and spectroscopic properties of copper(II) compounds containing nitrogen-sulphur donor ligands; the crystal and molecular structure of Aqua[1,7-bis(N-methylbenzimidazol-2'-yl)-2,6-dithiaheptane]copper(II) Perchlorate. J. Chem. Soc., Dalt. Trans 1984, 0, 1349-1356.

17. Cavaillé A; Joyeux B; Saffon-Merceron N; Nebra N; Fustier-Boutignona M; Mézailles N TriphosFe dinitrogen and dinitrogen-hydride complexes: relevance to catalytic $\mathrm{N}_{2}$ reductions, Chem. Commun 2018, 54, 11953-11956.

18. a)Examples of deriving the coupling between metal centers by NMR can be found in Pfirrmann S; Limberg C; Herwig C; Knispel C; Braun B; Bill E; Stösser R A reduced $\beta$-diketiminato-ligated Ni3H4 unit catalyzing H/D Exchange. J. Am. Chem. Soc 2010, 132, 13684-13691. [PubMed: 20828129] b) Tepper AWJW; Bubacco L; Canters GW Paramagnetic properties of the halidebound derivatives of oxidised tyrosinase investigated by $1 \mathrm{H}$ NMR spectroscopy. Chem. Eur. J 2006, 12, 7668-7675. [PubMed: 16927257]

19. Stoian SA; Vela J; Smith JM; Sadique AR; Holland PL; Münck E; Bominaar EL Mössbauer and computational study of an $\mathrm{N}_{2}$-bridged diiron diketiminate complex: parallel alignment of the iron spins by direct antiferromagnetic exchange with activated dinitrogen. J. Am. Chem. Soc 2006, 128 (31), 10181-10192. [PubMed: 16881648]

20 (a). Hoffman BM; Lukoyanov D; Yang ZY; Dean DR; Seefeldt L C. Mechanism of nitrogen fixation by nitrogenase: the next stage. Chem. Rev 2014, 114, 4041-4062. [PubMed: 24467365] (b)Lukoyanov D; Khadka N; Yang ZY; Dean DR; Seefeldt LC; Hoffman BM Reversible photoinduced reductive elimination of $\mathrm{H} 2$ from the nitrogenase dihydride state, the $\mathrm{E} 4(4 \mathrm{H})$ janus 
intermediate. J. Am. Chem. Soc 2016, 138, 1320-1327. [PubMed: 26788586] (c)Lukoyanov D; Khadka N; Yang Z-Y; Dean DR; Seefeldt LC; Hoffman BM Reductive elimination of H2 activates nitrogenase to reduce the $\mathrm{N} \equiv \mathrm{N}$ triple bond: Characterization of the $\mathrm{E} 4(4 \mathrm{H})$ Janus Intermediate in wild-type enzyme. J. Am. Chem. Soc 2016, 138, 10674-10683. [PubMed: 27529724] (d)Lukoyanov D; Yang ZY; Khadka N; Dean DR; Seefeldt LC; Hoffman BM Identification of a key catalytic intermediate semonstrates that nitrogenase is activated by the reversible exchange of $\mathrm{N}_{2}$ for $\mathrm{H}_{2}$. J. Am. Chem. Soc 2015, 137 (10), 3610-3615. [PubMed: 25741750] (e)Lukoyanov D; Yang Z-Y; Barney BM; Dean DR; Seefeldt LC; Hoffman BM Unification of reaction pathway and kinetic scheme for $\mathrm{N}_{2}$ reduction catalyzed by nitrogenase. Proc. Natl. Acad. Sci 2012, 109 (15), 5583-5587. [PubMed: 22460797]

21 (a). Baker MV; Field LD; Young DJ Formation of molecular hydrogen complexes of iron by the reversible protonation of iron dihydrides with alcohols. J. Chem. Soc. Chem. Commun 1988, 2, 546-548. Hills, A.; Hughes, D. L.; Jimenez-Tenorio, M.; Leigh, G. J.; Rowley, A. T. Bis[1,2bis(dimethylphosphino)ethane]dihydrogenhydridoiron(II) tetraphenylborate as a model for the function of nitrogenases. J. Chem. Soc. Dalt. Trans. 1993, 3041-3049.

22. Erickson NE; Fairhall AW Mössbauer spectra of iron in $\mathrm{Na} 2[\mathrm{Fe}(\mathrm{CO}) 4]$ and $\mathrm{Na}[\mathrm{Fe} 3(\mathrm{CO}) 11 \mathrm{H}]$ and comments regarding the structure of Fe3(CO)12. Inorg. Chem 1965, 4, 1320-1322.

23. Collman JP Disodium tetracarbonylferrate, a transition metal analog of a Grignard reagent. Acc. Chem. Res 1975, 8, 342-347.

24. (a)Bridged M-N2-M species should give rise to only one peak in the $15 \mathrm{~N}$ NMR spectra. See: Doyle LR; Hill PJ; Wildgoose GG.; Ashley AE Teaching old compounds new tricks: efficient N2 fixation by simple Fe(N2)(diphosphine) 2 complexes. Dalton. Trans 2016, 45, 7550-7554. [PubMed: 27075532] (b) Hazari N Homogeneous iron complexes for the conversion of dinitrogen into ammonia and hydrazine. Chem. Soc. Rev 2010, 39, 4044-4056. [PubMed: 20571678] (c)Eizawa, Field LD; Guest RW; Turner P Mixed-valence dinitrogen-bridged Fe(0)/Fe(II) complex. Inorg. Chem 2010, 49, 9086-9093. [PubMed: 20815362] (d)A.; Arashiba K; Tanaka H; Kuriyama S; Matsuo Y; Nakajima K; Yoshizawa K; Nishibayashi Y Remarkable catalytic activity of dinitrogen-bridged dimolybdenum complexes bearing NHC-based PCP-pincer ligands toward nitrogen fixation. Nat. Commun 2017, 8, 1-12. [PubMed: 28232747] (e)Kokubo Y; Yamamoto C; Tsuzuki K; Nagai T; Katayama A; Ohta T; Ogura T; Wasada-Tsutsui Y; Kajita Y; Kugimiya S; Masuda $H$ Dinitrogen fixation by vanadium complexes with a triamidoamine ligand. Inorg. Chem 2018, 57, 11884-11894. [PubMed: 30199244] (f)Lindley BM; van Alten RS; Finger M; Schendzielorz F; Würtele C; Miller AJM; Siewert I; Schneider S Mechanism of chemical and electrochemical N2 splitting by a rhenium pincer complex. J. Am. Chem. Soc 2018, 140, 79227935. [PubMed: 29856611]

25. Other formal d10 species also suffer from decomposition upon addition of a crown ether. See: Mokhtarzadeh CC; Margulieux GW; Carpenter AE; Weidemann N; Moore CE; Rheingold A; Figueroa JS Synthesis and protonation of an encumbered iron tetraisocyanide dianion. Inorg. Chem 2015, 54, 5579-5587. [PubMed: 25965161]

26. Kruck T; Prasch A Synthese und Struktur der tetrakis(trifluorphosphin)-metalldihydride und metallate(-II) von Eisen, Ruthenium und Osmium. Z. Anorg. Allg. Chem 1969, 371, 1-22.

27. Jonas K; Schieferstein L; Krüger C; Tsay Y-H Tetrakis(ethylene)irondilithium and Bis( $\eta 4-1,5-$ cyclooctadiene) irondilithium. Angew. Chemie Int. Ed 1979, 18, 550-551.

28. Martin R; Fürstner A Reversal of reactivity cross-coupling of alkyl halides with aryl Grignard reagents catalyzed by a low-valent iron complex. Angew. Chem. Int. Ed 2004, 43, 3955-3957.

29. Brennessel WW; Ellis JE [Fe(CNXyl)4]2-: an isolable and structurally characterized homoleptic isocyanidemetalate dianion. Angew. Chem. Int. Ed 2007, 46, 598-600.

30. Rosa P. Orsay; Mézailles N; Ricard L; Mathey F; Floch P. Le; Jean Y Dianionic iron and ruthenium(2-) bisphosphinine complexes: a formal d10 ruthenium complex with a square planar geometry. Angew. Chem. Int. Ed 2001, 40, 1251-1253.

31. Cullen WR; Crow JP; Herring FG; Sams JR; Tapping RL Mössbauer and electron paramagnetic resonance studies of some iron nitrosyl complexes. Inorg. Chem 1971, 10, 1616-1623.

32. Farmery K; Kilner M; Greatrex R; Greenwood NN Structural studies of the carbonylate and carbonyl hydride anions of iron. J. Chem. Soc. A, 1969, 2339-2345. 
33 (a). Moret M-E; Peters JC Terminal iron dinitrogen and iron imide complexes supported by a tris(phosphino)borane ligand. Angew. Chem. Int. Ed 2011, 50, 2063-2067.(b)Mankad NP; Whited MT; Peters JC Terminal Fe ${ }^{\mathrm{I}}-\mathrm{N}_{2}$ and $\mathrm{Fe}$ II ...H-C interactions supported by tris(phosphino)silyl ligands. Angew. Chem., Int. Ed 2007, 46, 5768-5771.

34. Moret M; Peters JC N 2 Functionalization at iron metallaboratranes. J. Am. Chem. Soc 2011, 4350, 18118-18121.

35. McWilliams SF; Bill E; Lukat-Rodgers G; Rodgers KR; Mercado BQ; Holland PL Effects of $\mathrm{N}_{2}$ binding mode on iron-based functionalization of dinitrogen to form an iron(III) hydrazido complex. J. Am. Chem. Soc 2018, 140, 8586-8598. [PubMed: 29957940]

36. Piascik AD; Li R; Wilkinson HJ; Green JC; Ashley AE Fe-catalyzed conversion of N2 to $\mathrm{N}(\mathrm{SiMe} 3) 3$ via an Fe-hydrazido resting state. J. Am. Chem. Soc 2018, 10691-10694. [PubMed: 30114921]

37. Piascik AD; Hill PJ; Crawford AD; Doyle LR; Green JC; Ashley AE Cationic silyldiazenido complexes of the Fe(diphosphine)2(N2) platform: structural and electronic models for an elusive first intermediate in N2 fixation. Chem. Commun 2017, 53, 7657-7660.

38. Rudd P. Alex; Planas N; Bill E; Gagliardi L; Lu CC Dinitrogen Activation at Iron and Cobalt Metallalumatranes Eur. J. Inorg. Chem 2013, 2 (22-23), 3898-3906.

39 (a). Lee Y; Mankad NP; Peters JC Triggering N2 uptake via redox-induced expulsion of coordinated NH3 and N2 silylation at trigonal bipyramidal iron, Nat. Chem 2010, 558-565. [PubMed: 20571574] (b)Ung G; Peters JC Low temperature N2 binding to 2-coordinate L2Fe0 enables reductive trapping of L2FeN2- and NH3 generation. Angew. Chem. Int. Ed 2015, 54, 532-535. 

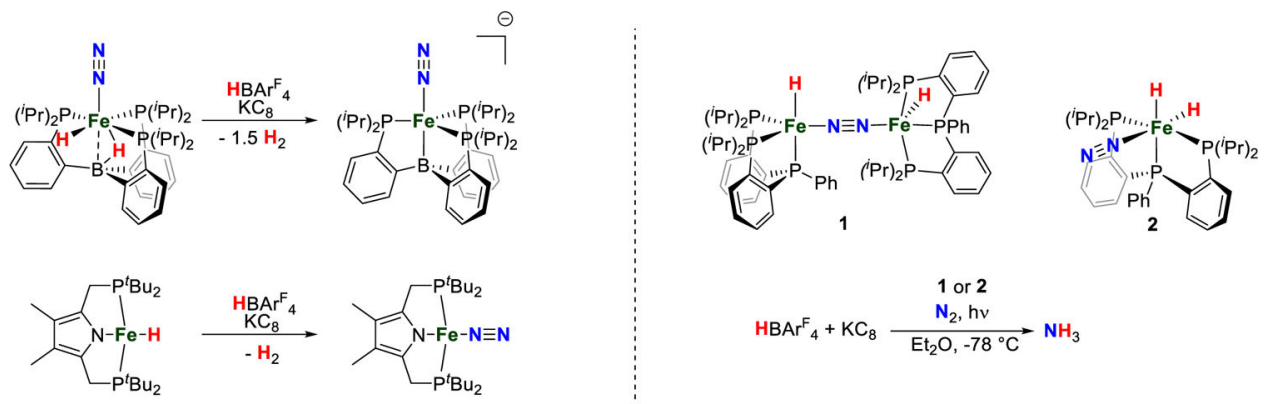

Figure 1.

(Left) Protonation and reduction of off-path iron hydrides results in the formation of on-path species capable of $\mathrm{N}_{2} \mathrm{RR}$. (Right) Previously reported iron based catalysts and the conditions under which light enhanced nitrogen fixation by mercury lamp irradiation was observed. ${ }^{1 \mathrm{~g}}$ 


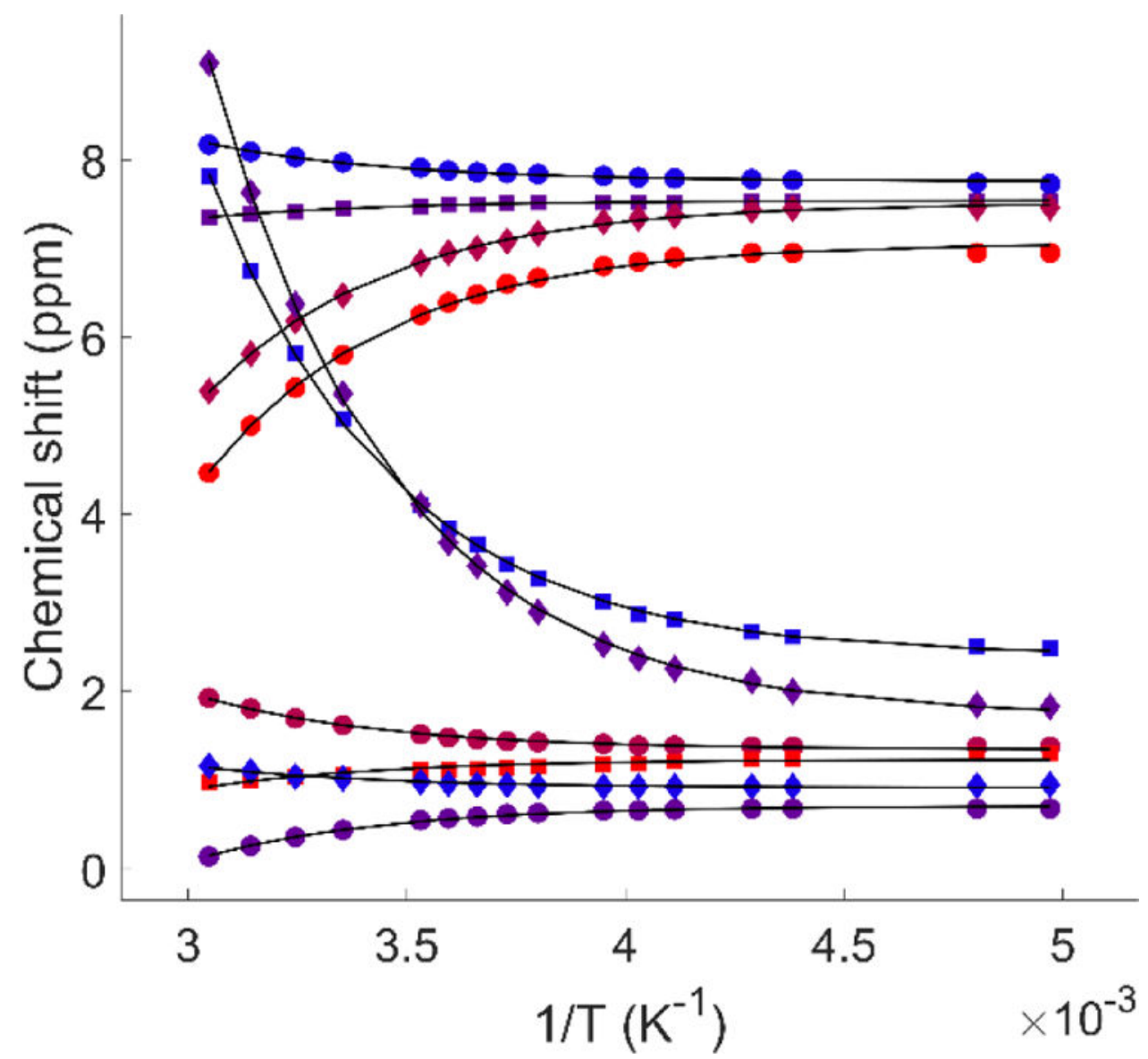

Figure 2.

The ${ }^{1} \mathrm{H}$ NMR chemical shifts of 6 plotted as a function of 1/T display a deviation from Curie-behavior, due to the population of a low-lying exited state. A fit of the data, indicated with black lines, gives $\mathrm{J}=-940 \pm 9.4 \mathrm{~cm}^{-}$. 


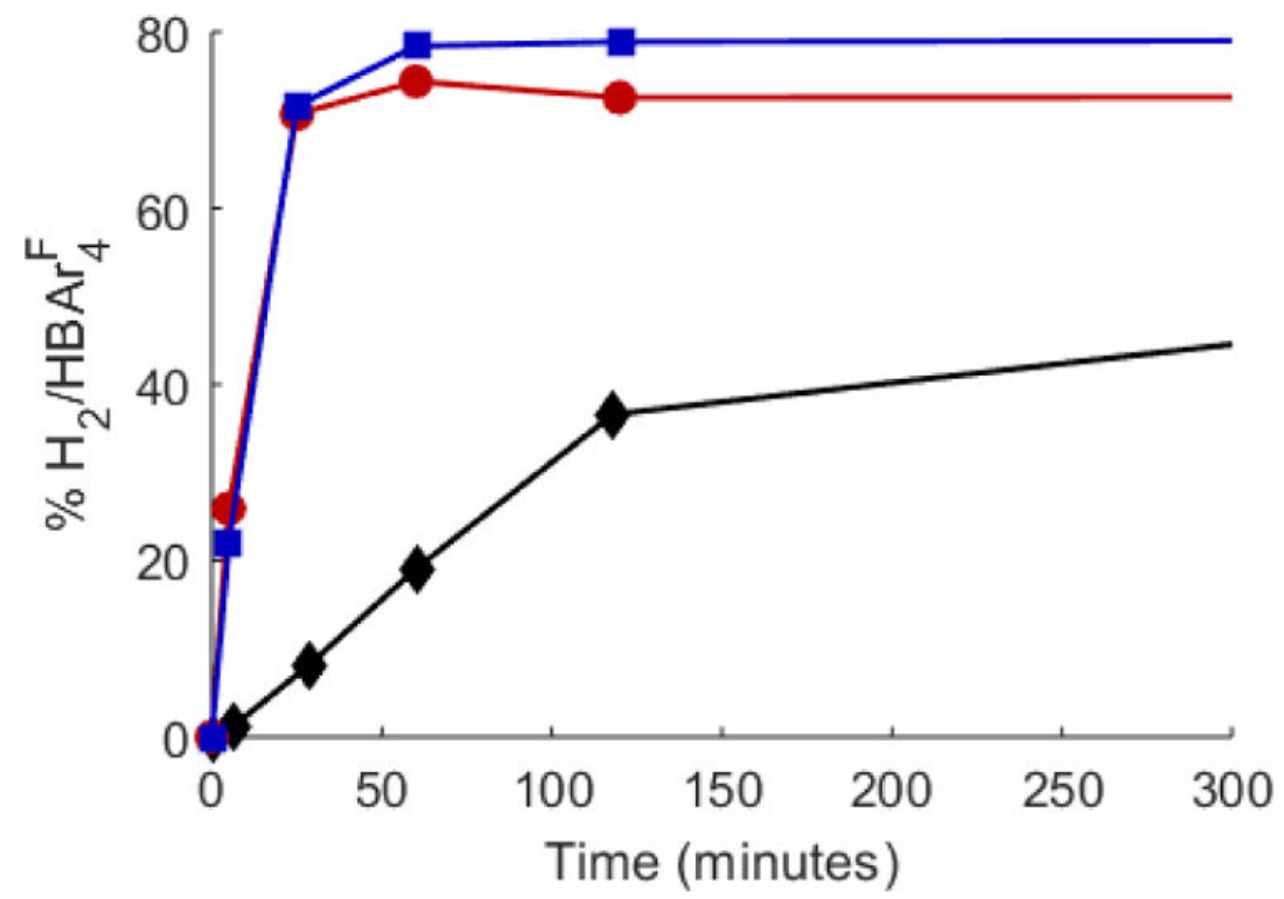

Figure 3.

Time profiles of the formation of $\mathrm{H}_{2}$ from $\mathrm{HBAr}^{\mathrm{F}}$ and $\mathrm{KC}_{8}$ in $\mathrm{Et}_{2} \mathrm{O}$ at $-78{ }^{\circ} \mathrm{C}$. Data are presented for the background reaction of these reagents in the absence of catalyst (black diamonds), as well as in the presence of either $\mathbf{2}$ (red circles) or $\mathbf{5}$ (blue squares). Each time course was collected continuously from a single experiment. The final data points, recorded after 16 hours, are omitted from the graph. 

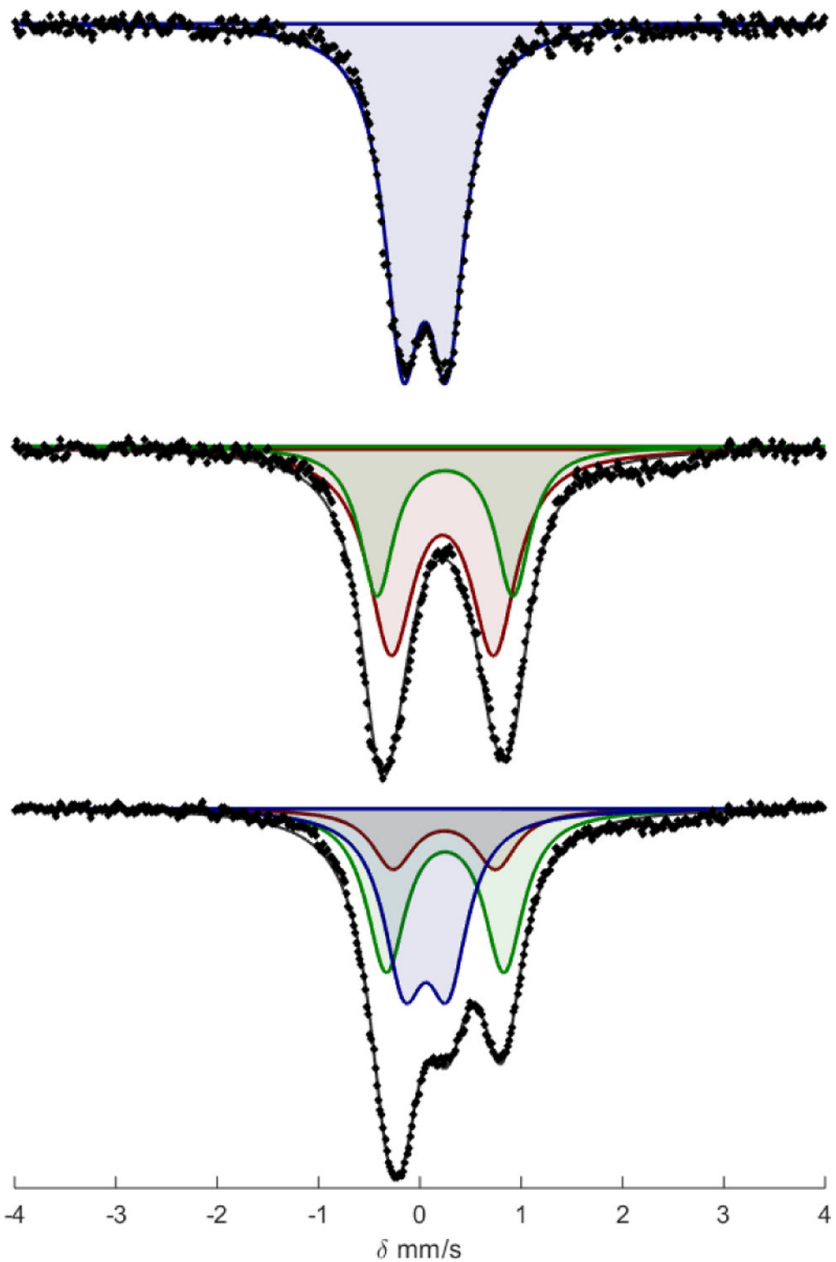

Figure 4.

Frozen solution Mössbauer spectra collected at $80 \mathrm{~K}$ in the presence of a $50 \mathrm{mT}$ parallel magnetic field. Spectra of a catalytic mixture, using 2 (blue) as precatalysts (top), quenched after 5 minutes (middle) and 30 minutes (bottom) of stirring. For parameters of individual components, see SI. 

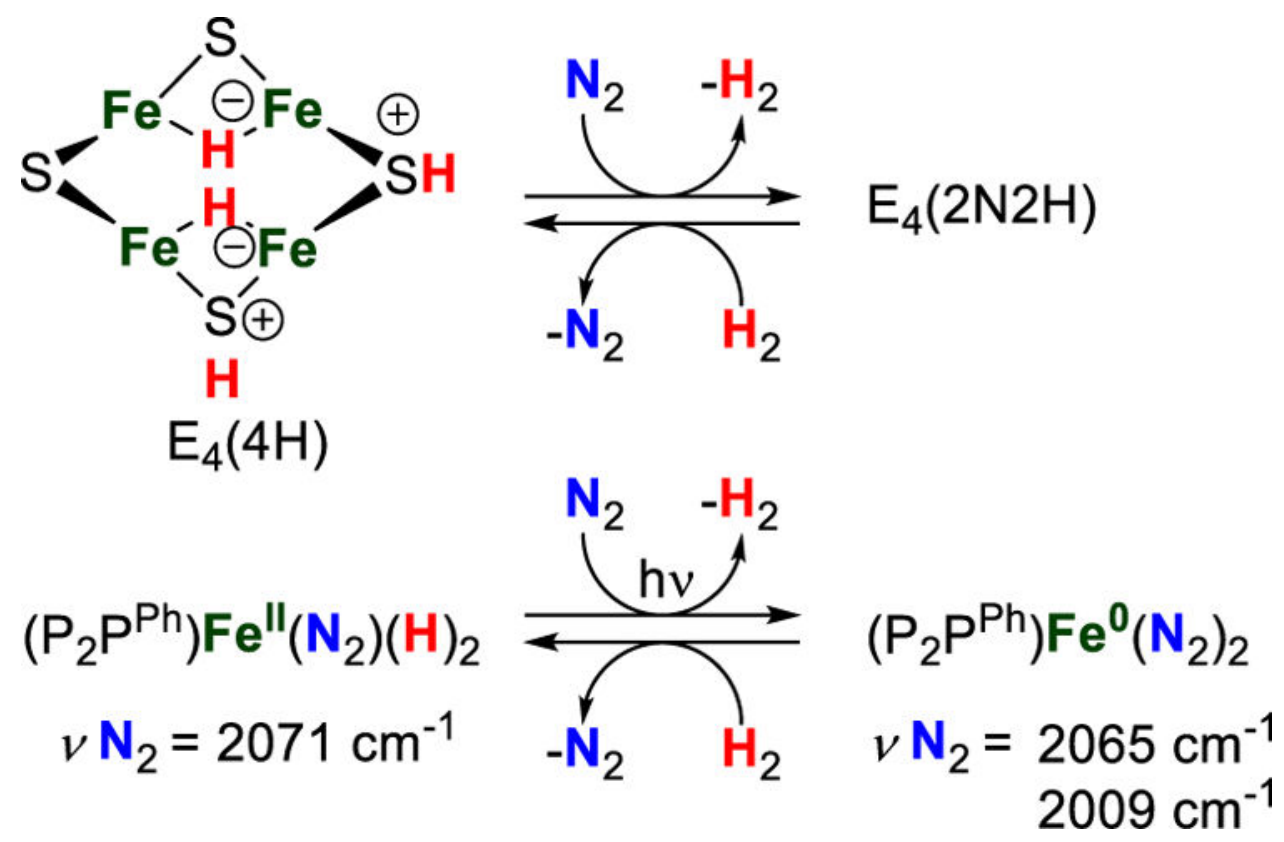

Figure 5.

(Top) $\mathrm{H}_{2}$ elimination from the $\mathrm{E}_{4}$ state resulting in a more electron rich center is proposed from Mo-nitrogenase, and Fe-nitrogenase. Light induced reductive elimination of $\mathrm{H}_{2}$ from 2 leads to increased back-bonding due to the formal reduction from $\mathrm{Fe}^{\mathrm{II}}$ to $\mathrm{Fe}^{0}$ (Bottom). 


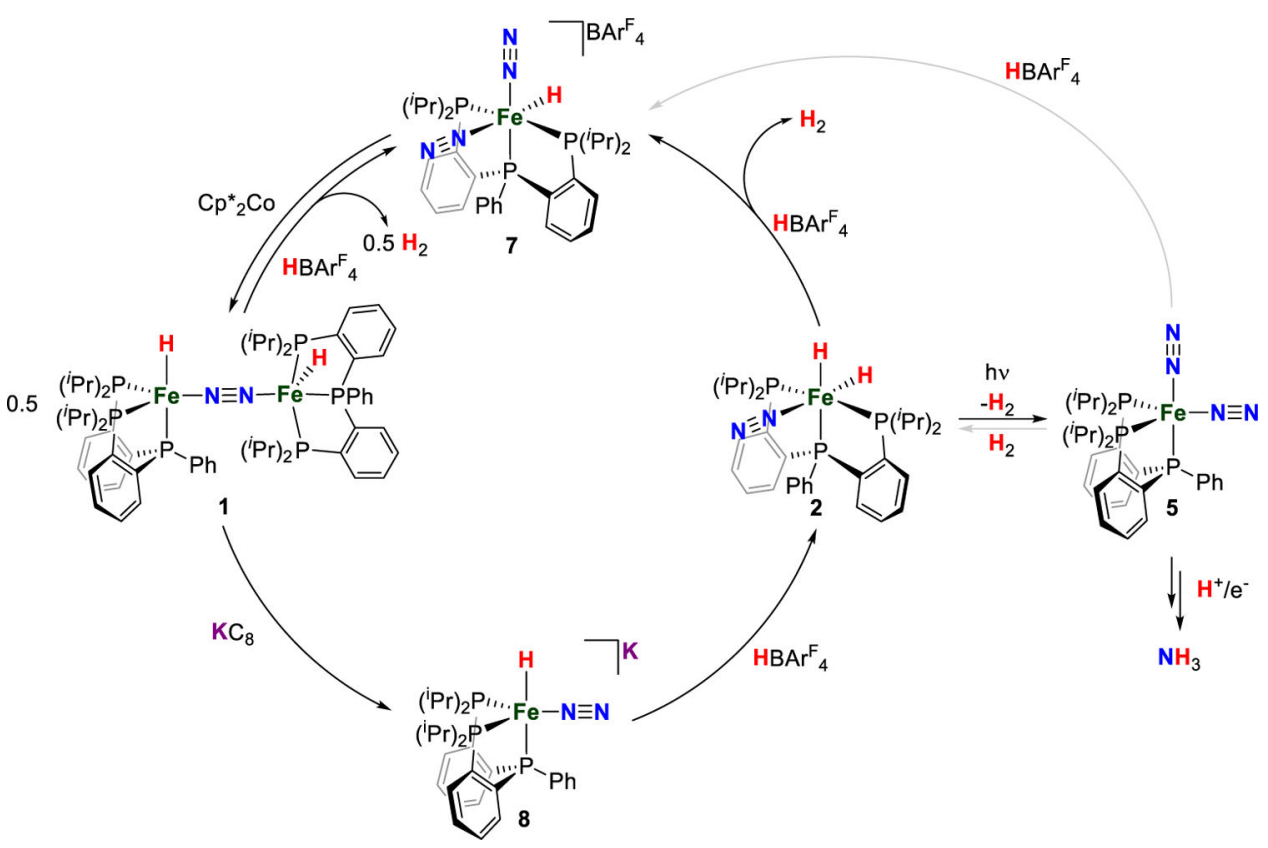

Figure 6.

Summary of the stoichiometric reactivity observed with $\left[\mathrm{P}_{2} \mathrm{P}^{\mathrm{Ph}} \mathrm{Fe}\left(\mathrm{N}_{2}\right)_{\mathrm{x}}(\mathrm{H})_{\mathrm{y}}\right]^{+/ 0 /-}$. Grey arrows indicate reactions that do not occur at $-78{ }^{\circ} \mathrm{C}$. Black arrows indicate reactions that occur at $-78^{\circ} \mathrm{C}$ 

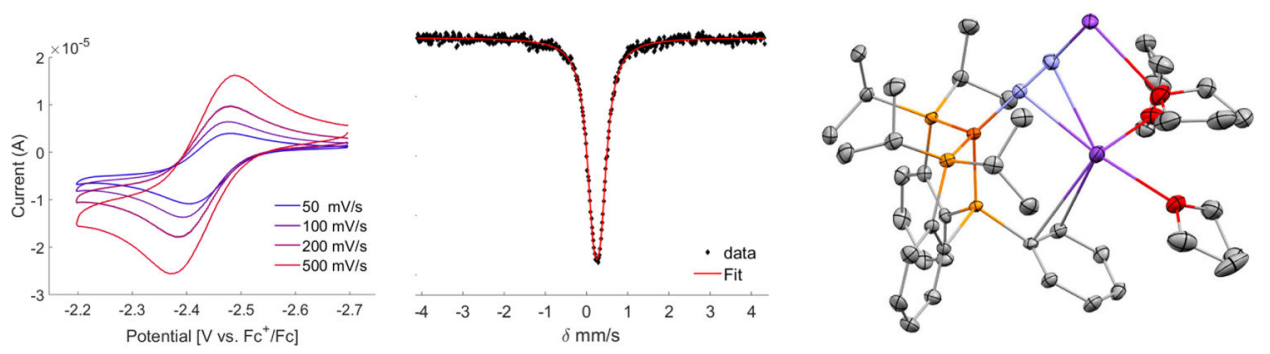

Figure 7.

(Left) Cyclic voltammetry data of $\mathbf{9}$ scanning cathodically, (Middle) Mössbauer spectrum of 10, (Right) Asymmetric unit of the XRD structure of 10. In the dimeric structure, the iron centers are related by an inversion center. Hydrogen atoms and disorder in one of the $i$-Pr moieties are omitted for clarity. 

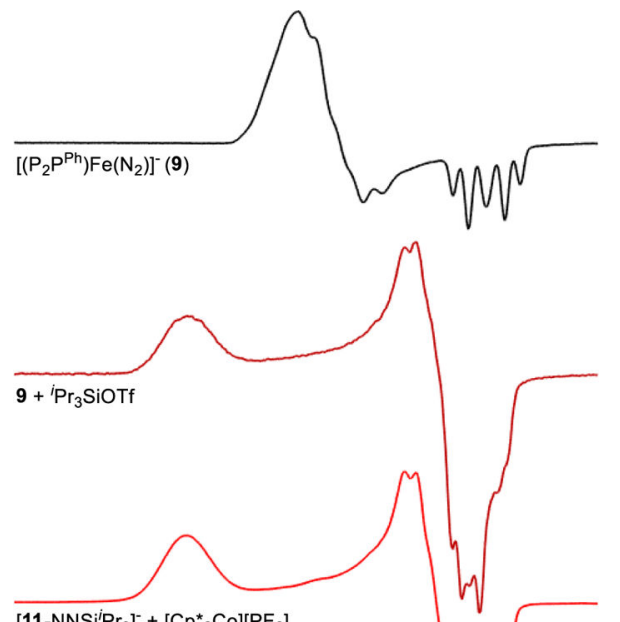

$\left[11-\mathrm{NNSi}^{\mathrm{i}} \mathrm{Pr}_{3}\right]^{-}+\left[\mathrm{Cp}_{2}{ }_{2} \mathrm{Co}\right]\left[\mathrm{PF}_{6}\right]$
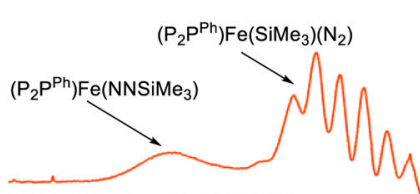

$\mathrm{Fe}\left(\mathrm{SiMe}_{3}\right)\left(\mathrm{N}_{2}\right)$

$\left[11-\mathrm{NNSiMe}_{3}\right]^{-}+\left[\mathrm{Cp}^{\star}{ }_{2} \mathrm{Co}\right]\left[\mathrm{PF}_{6}\right]$

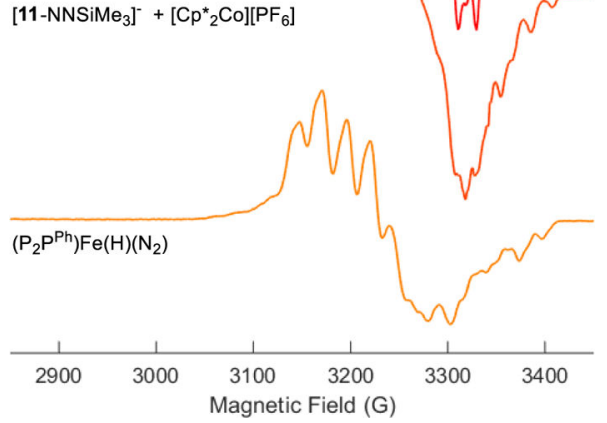

Figure 8.

Collected EPR data; (Black) Spectrum of $\left[\left(\mathrm{P}_{2} \mathrm{P}^{\mathrm{Ph}}\right) \mathrm{Fe}\left(\mathrm{N}_{2}\right)\right][18$-crown-6)] (9). (Maroon) Spectrum observed upon addition of ${ }^{\mathrm{i}} \mathrm{Pr}_{3} \mathrm{SiOTf}$ to 9 , showing conversion to 12-NNSii $\mathrm{Pr}_{3}$. (Red) Spectrum of 12-NNSi $\mathrm{Pr}_{3}$ obtained by oxidation of [11-NNSi $\left.{ }^{i} \mathrm{Pr}_{3}\right]^{-}$with $\left[\mathrm{Cp}_{2}{ }_{2} \mathrm{Co}\right]$ $\left[\mathrm{PF}_{6}\right]$. (Orange) Spectrum of the oxidation of [11-NNSiMe $]^{-}$with $\left[\mathrm{Cp}_{2}{ }_{2} \mathrm{Co}\right]\left[\mathrm{PF}_{6}\right]$ showing the formation of $\left(\mathrm{P}_{2} \mathrm{P}^{\mathrm{Ph}}\right) \mathrm{Fe}\left(\mathrm{SiMe}_{3}\right)\left(\mathrm{N}_{2}\right)$ and $\left(\mathrm{P}_{2} \mathrm{P}^{\mathrm{Ph}}\right) \mathrm{Fe}\left(\mathrm{NNSiMe}_{3}\right)$. (Yellow) Spectrum of $\left(\mathrm{P}_{2} \mathrm{P}^{\mathrm{Ph}}\right) \mathrm{Fe}(\mathrm{H})\left(\mathrm{N}_{2}\right){ }^{2}$ 

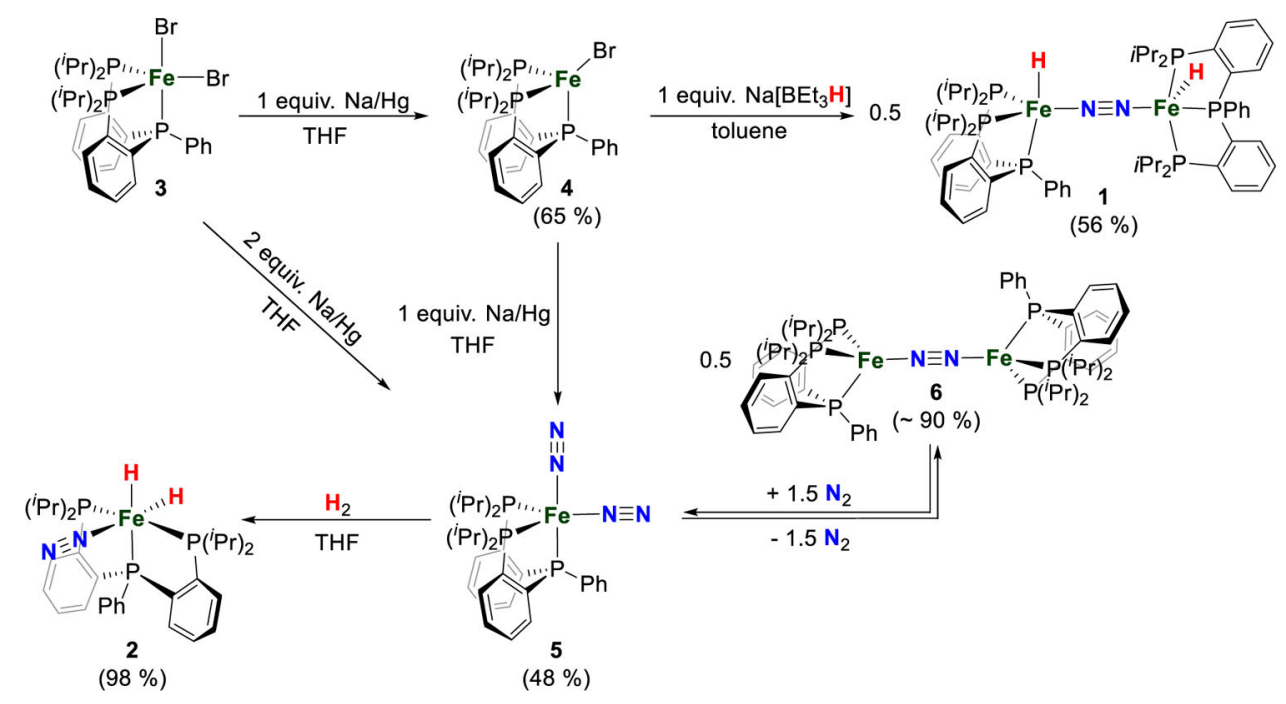

Scheme 1.

Preparation of dinitrogen adducts of $\left(\mathrm{P}_{2} \mathrm{P}^{\mathrm{Ph}}\right) \mathrm{Fe}$ from the bromide precursors 3 and 4 . 


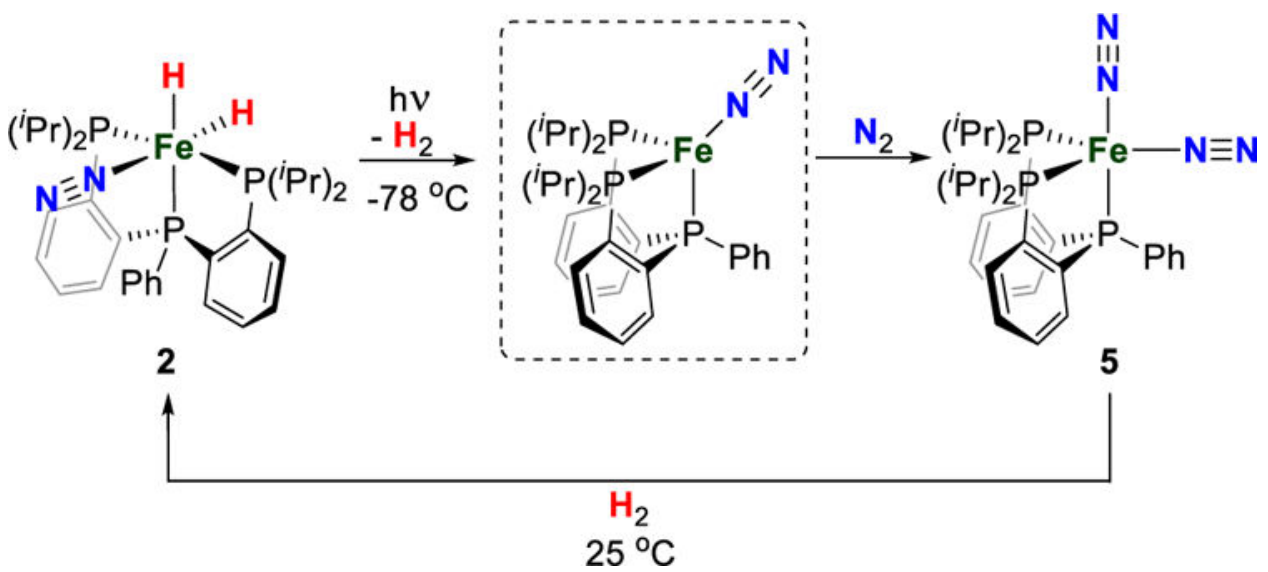

Scheme 2.

Light induced reductive elimination of $\mathrm{H}_{2}$ from 2 leads to a transient unobserved four coordinate species, which binds $\mathrm{N}_{2}$ to form $\mathbf{5}$. The $\mathrm{H}_{2}$ elimination is reversible as $\mathbf{5}$ reacts back to 2 in the presence of $\mathrm{H}_{2}$. 

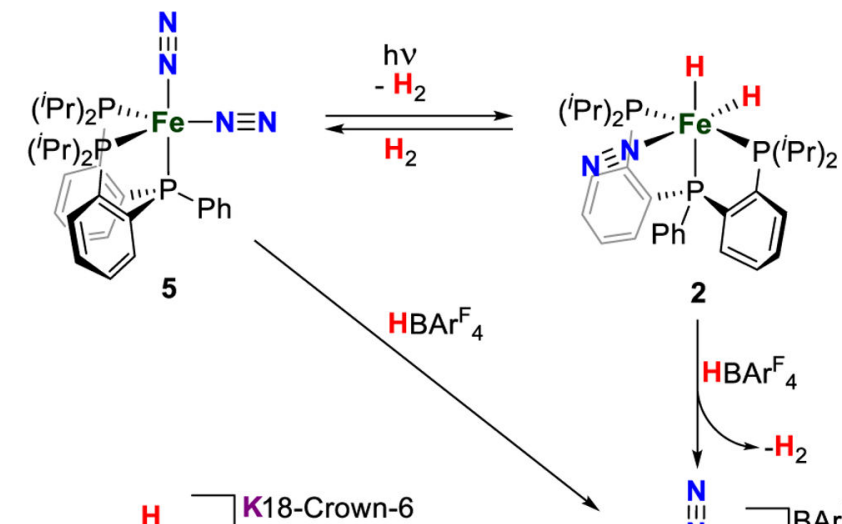

2
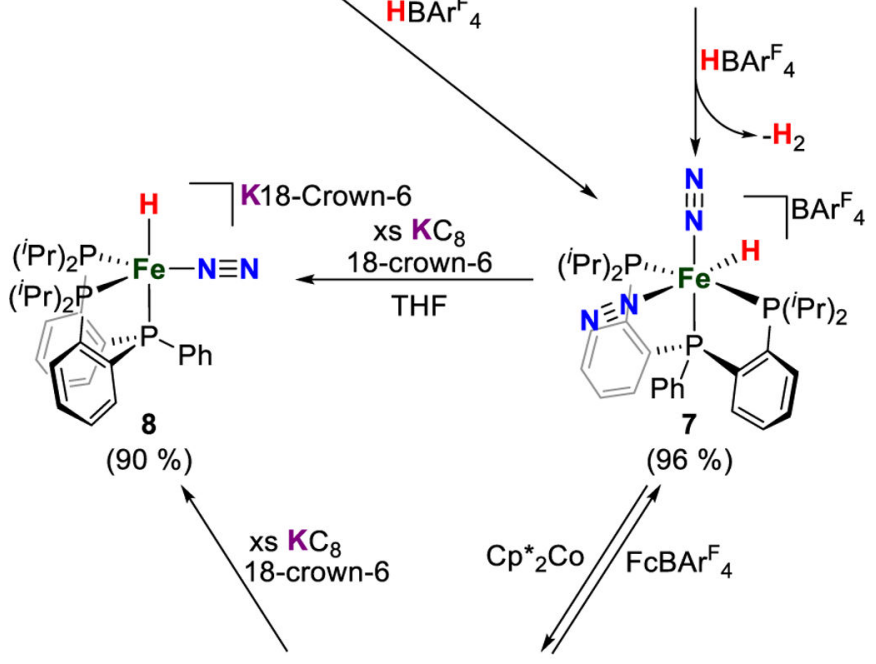

THF

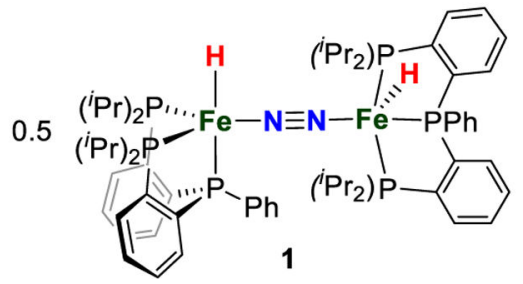

Scheme 3.

Pathways towards 7 and 8 . Preparative and NMR scale reactions were performed at $-78{ }^{\circ} \mathrm{C}$. 


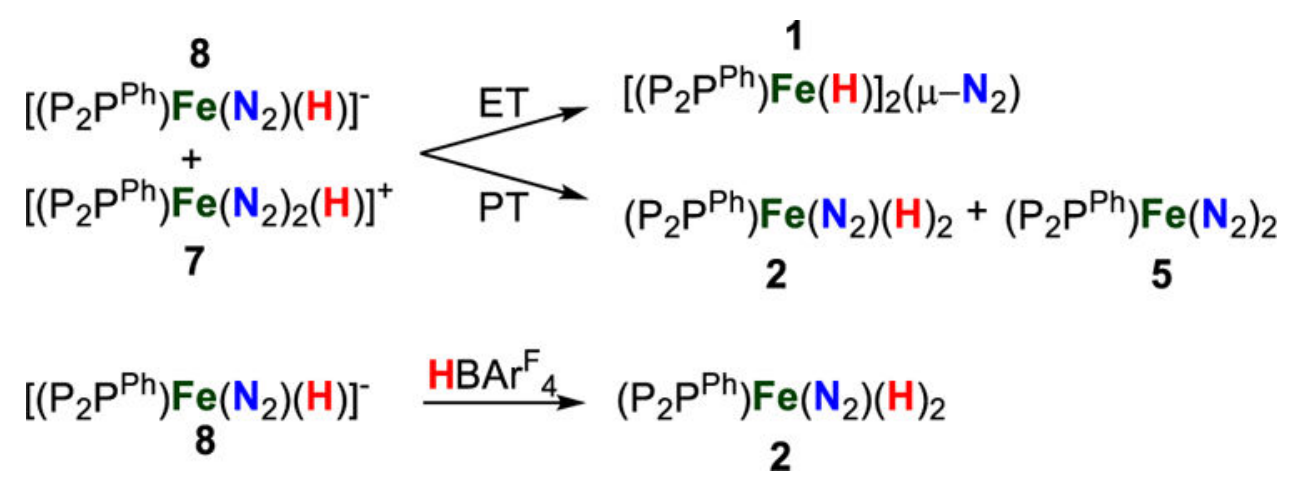

Scheme 4.

Electron and proton transfer from $\mathbf{7}$ and $\mathbf{8}$ 


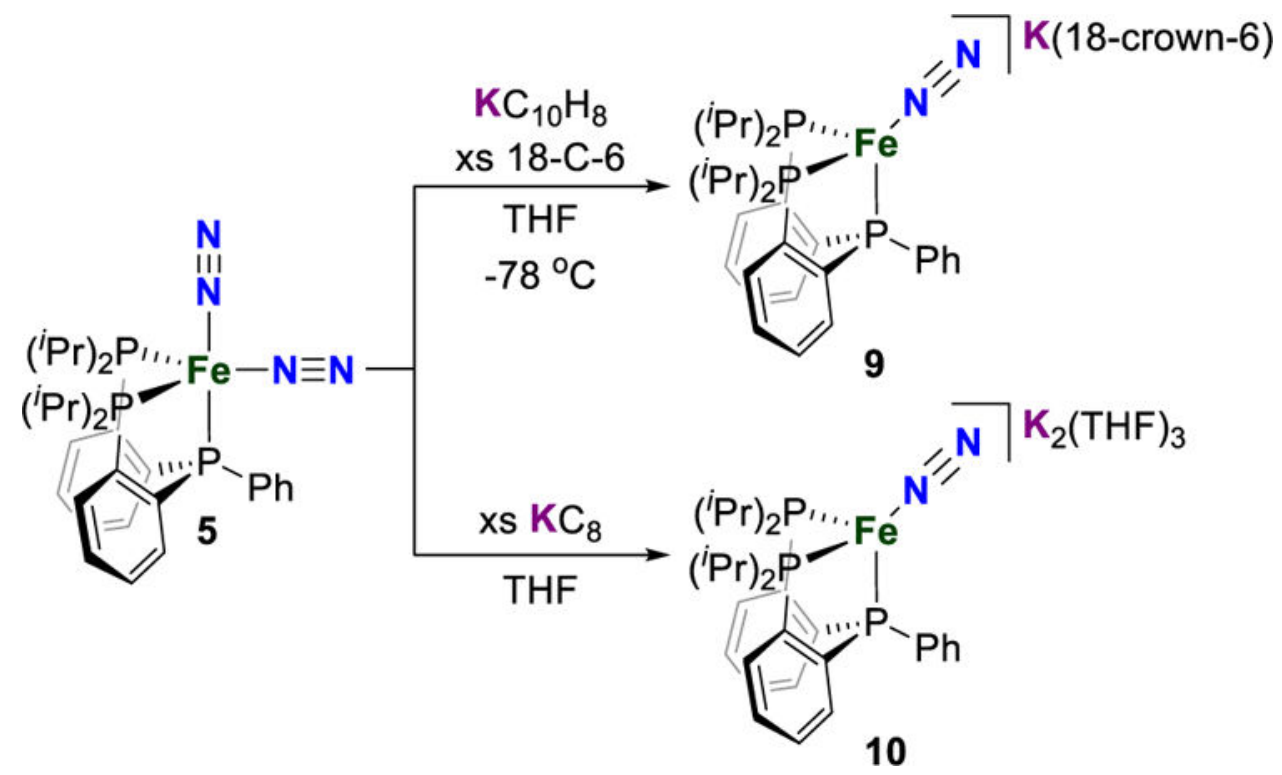

Scheme 5.

The reduction of $\mathbf{5}$ results in the formation of $\mathbf{9}$ or $\mathbf{1 0}$ depending on the equivalents of reductant used. 

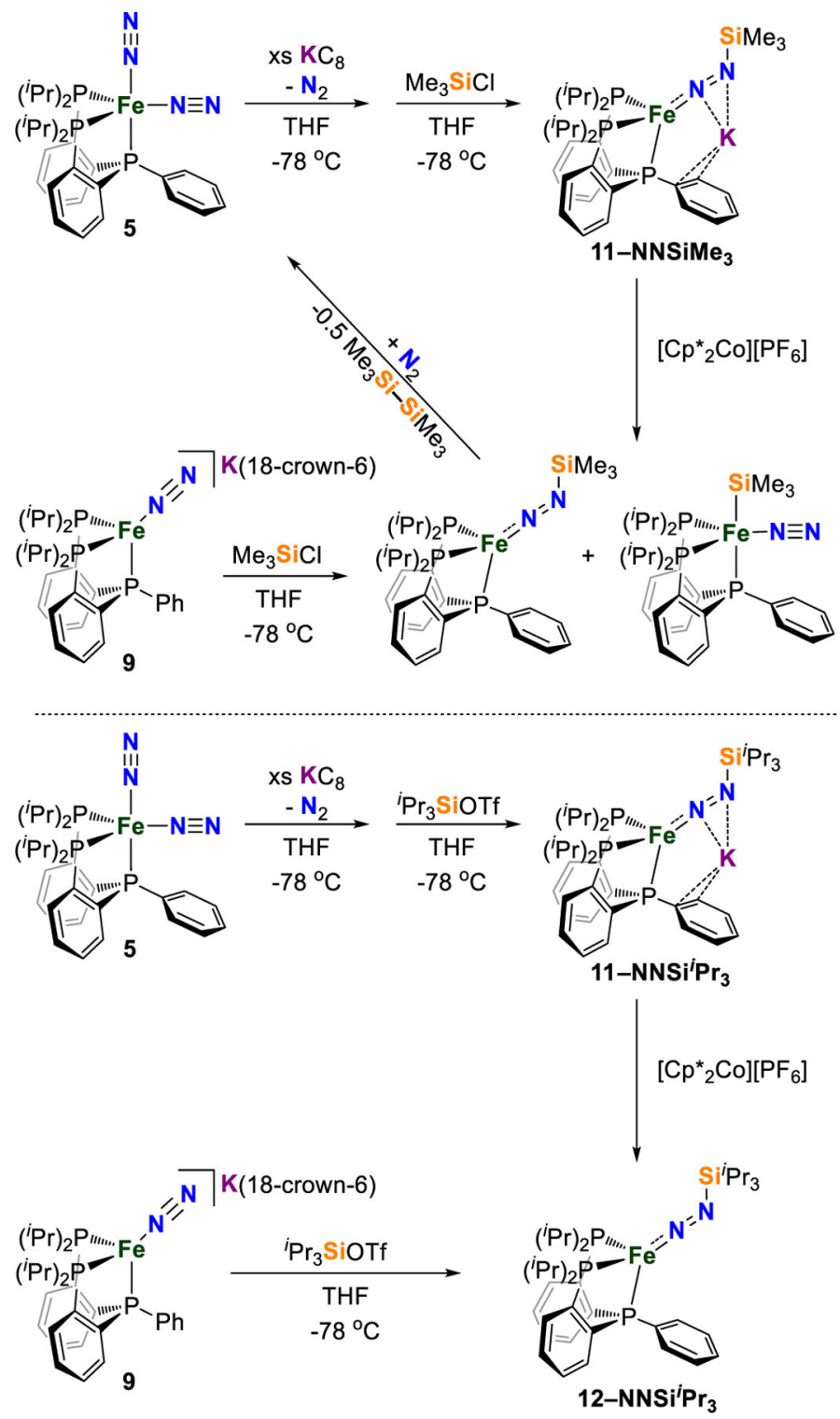

Scheme 6.

Synthesis of Fe-silyldiazenido complexes [11NNSiMe 3$] \mathrm{K},\left[11-\mathrm{NNSi}^{i} \mathrm{Pr}_{3}\right] \mathrm{K}$ and 12NNSi ${ }^{i} \operatorname{Pr}_{3}$. 